\title{
Chemical characterization of fine particulate matter emitted by peat fires in Central Kalimantan, Indonesia, during the 2015 El Niño
}

\author{
Thilina Jayarathne ${ }^{1}$, Chelsea E. Stockwell ${ }^{2}$, Ashley A. Gilbert ${ }^{1}$, Kaitlyn Daugherty ${ }^{1}$, Mark A. Cochrane ${ }^{3}$, \\ Kevin C. Ryan ${ }^{4}$, Erianto I. Putra ${ }^{3,5}$, Bambang H. Saharjo ${ }^{5}$, Ati D. Nurhayati ${ }^{5}$, Israr Albar ${ }^{5, a}$, Robert J. Yokelson ${ }^{2}$, \\ and Elizabeth A. Stone ${ }^{1,6}$ \\ ${ }^{1}$ University of Iowa, Department of Chemistry, Iowa City, IA 52242, USA \\ ${ }^{2}$ University of Montana, Department of Chemistry, Missoula, MT 59812, USA \\ ${ }^{3}$ Appalachian Laboratory, University of Maryland Center for Environmental Science, Frostburg, MD 21532, USA \\ ${ }^{4}$ FireTree Wildland Fire Sciences, L.L.C., Missoula, MT 59801, USA \\ ${ }^{5}$ Bogor Agricultural University, Faculty of Forestry, Bogor 16680, Indonesia \\ ${ }^{6}$ University of Iowa, Chemical and Biochemical Engineering, Iowa City, IA 52242, USA \\ ${ }^{a}$ now at: Directorate General of Climate Change, Ministry of Environment and Forestry, Jakarta 10270, Indonesia
}

Correspondence: Elizabeth A. Stone (betsy-stone@uiowa.edu)

Received: 16 March 2017 - Discussion started: 12 June 2017

Revised: 27 October 2017 - Accepted: 14 December 2017 - Published: 21 February 2018

\begin{abstract}
Fine particulate matter $\left(\mathrm{PM}_{2.5}\right)$ was collected in situ from peat smoke during the 2015 El Niño peat fire episode in Central Kalimantan, Indonesia. Twenty-one PM samples were collected from 18 peat fire plumes that were primarily smoldering with modified combustion efficiency (MCE) values of $0.725-0.833$. PM emissions were determined and chemically characterized for elemental carbon (EC), organic carbon (OC), water-soluble OC, water-soluble ions, metals, and organic species. Fuel-based $\mathrm{PM}_{2.5}$ mass emission factors (EFs) ranged from 6.0 to $29.6 \mathrm{~g} \mathrm{~kg}^{-1}$ with an average of $17.3 \pm 6.0 \mathrm{~g} \mathrm{~kg}^{-1}$. EC was detected only in 15 plumes and comprised $\sim 1 \%$ of PM mass. Together, OC (72\%), EC (1\%), water-soluble ions (1\%), and metal oxides $(0.1 \%)$ comprised $74 \pm 11 \%$ of gravimetrically measured PM mass. Assuming that the remaining mass is due to elements that form organic matter (OM; i.e., elements $\mathrm{O}$, $\mathrm{H}, \mathrm{N}$ ) an OM-to-OC conversion factor of 1.26 was estimated by linear regression. Overall, chemical speciation revealed the following characteristics of peat-burning emissions: high OC mass fractions $(72 \%)$, primarily water-insoluble OC $(84 \pm 11 \% \mathrm{C})$, low EC mass fractions $(1 \%)$, vanillic to syringic acid ratios of 1.9 , and relatively high $n$-alkane contributions to OC $(6.2 \% \mathrm{C})$ with a carbon preference index of $1.2-1.6$. Comparison to laboratory studies of peat combustion revealed similarities in the relative composition of PM
\end{abstract}

but greater differences in the absolute EF values. The EFs developed herein, combined with estimates of the mass of peat burned, are used to estimate that 3.2-11 Tg of $\mathrm{PM}_{2.5}$ was emitted to atmosphere during the 2015 El Niño peatland fire event in Indonesia. Combined with gas-phase measurements of $\mathrm{CO}_{2}, \mathrm{CO}, \mathrm{CH}_{4}$, and volatile organic carbon from Stockwell et al. (2016), it is determined that OC and EC accounted for 2.1 and $0.04 \%$ of total carbon emissions, respectively. These in situ EFs can be used to improve the accuracy of the representation of Indonesian peat burning in emission inventories and receptor-based models.

\section{Introduction}

In recent decades, peatland fires in Southeast Asia, especially the Indonesian provinces of Sumatra, Kalimantan, and Papua as well as Malaysian Borneo, have become more frequent in occurrence (Page et al., 2009; Langner and Siegert, 2009; Van der Werf et al., 2010). Major peat-burning events have coincided with the El Niño Southern Oscillation (e.g., 19971998, 2006, 2015), during which warmer conditions decrease dry season precipitation, which lowers the water table of peatlands, increases their flammability, and promotes longerrange transport of the smoke (Reid et al., 2013). Within a sea- 
son, meteorological factors contribute to major peat-burning pollution events and transport, including typhoons and wind patterns (Wang et al., 2013). Notably, even in non-El Niño years, peat burning remains an important source of biomass burning emissions in Southeast Asia (Reid et al., 2013). The 2015 peatland fire episode that occurred SeptemberNovember 2015 occurred during an El Niño year and was reported as the strongest peatland fire episode since 1997-1998 (Parker et al., 2016; Koplitz et al., 2016; Huijnen et al., 2016). The 2015 fires burned $\sim 1$ million ha of tropical forests and peatlands in Indonesia, releasing $\sim 0.2 \mathrm{Pg} \mathrm{C}$ of carbon to the atmosphere (Huijnen et al., 2016). However, these values are well below the 1997-1998 estimates of $\sim 2$ million ha of burned peatland area that released $\sim 1.7 \mathrm{PgC}$ of carbon to the atmosphere in 2015 (Page et al., 2002; Chisholm et al., 2016; Huijnen et al., 2016; Tacconi, 2003). The 2015 peatland fire smoke also impacted neighboring Singapore, Malaysia, Thailand and Philippines with an estimated economic loss greater than USD 16 billion to their GDPs due to declines in productions and services during the event, in addition to long-term impacts to human health and the environment (Glover and Jessup, 2006; Chisholm et al., 2016; WorldBank, 2016). Negative health effects due to inhalation of peat smoke were widely reported during this catastrophe (Koplitz et al., 2016). In Palangka Raya, the capital of Central Kalimantan, $\mathrm{PM}_{10}$ levels reached up to $3741 \mathrm{\mu g} \mathrm{m}^{-3}$, nearly 2 orders of magnitude higher than the World Health Organization (WHO) guideline for $24 \mathrm{~h} \mathrm{PM}_{10}$ exposure (Stockwell et al., 2016; WHO, 2005). It was estimated that more than 40 million people suffered from continuous exposure to peat smoke during this episode and significant increase of premature deaths were reported due to respiratory and cardiovascular diseases (Koplitz et al., 2016). Despite the substantial environmental, socioeconomic, and health impacts, the peatland fire emissions are still under-studied with respect to their chemical and physical properties.

Peatlands are globally distributed over $\sim 400$ Mha land area, hold $\sim 550 \mathrm{MgC} \mathrm{ha}^{-1}$ of carbon per $1 \mathrm{~m} \mathrm{depth}$, and can reach depths of $20 \mathrm{~m}$. It has been estimated that $\sim 5.4 \times$ $10^{14} \mathrm{~kg}$ of carbon are stored underground in peat deposits, accounting for a significant fraction (44-71\%) of the terrestrial carbon pool (Maltby and Immirzi, 1993; Yu et al., 2010). Tropical peatlands particularly in Malaysian and Indonesian lowlands are frequently converted to agricultural croplands, commercial forests, or pasture by draining the peatlands (Maltby and Immirzi, 1993). During 1996-1999 the Indonesian government excavated more than $4000 \mathrm{~km}$ of drainage channels throughout 1 Mha of peatland to cultivate rice under the former Mega Rice Project (Page et al., 2009). After the project was abandoned in 1999, deforested and degraded peatlands were covered with secondary vegetation (Page et al., 2009). In recent decades, Indonesian peatland fires have occurred more frequently, intensively, and extensively. Degraded peatlands are at high risk of uncontrolled fire, because dry peat is highly combustible and secondary vegetation is more fire-prone than the original forest (Langner and Siegert, 2009; Page et al., 2002, 2009). Fires first occur in aboveground vegetation, then enter into the carbon-rich soils where they smolder and can spread slowly beneath the surface until the peatland is flooded during the next monsoon (Page et al., 2009). The burned areas do not easily regenerate to primary vegetation; instead, they are converted into ferns with patchy secondary vegetation that are prone to repeat fires (Chisholm et al., 2016).

Peat contains more than $85 \%$ organic matter $(\mathrm{OM})$ by dry mass that is made of plant tissues at varying stages of decomposition, with major organic compound classes being cellulose, hemicellulose, lignin, cutin, humic acid, and fulvic acid (Dehmer, 1995; Zulkifley et al., 2015; Dizman et al., 2015). Peat is categorized as fibric, hemic, or sapric based on the degree of decomposition. Fibric peat is the least degraded type with higher fiber content, while sapric peat is the most degraded peat type with an amorphous structure, and hemic peat has intermediate properties (Huat et al., 2011). Thus, peat soils carry biomarkers indicative of floral origin and these could be potentially used to identify peatland fire emissions. Levoglucosan, mannosan, syringaldehyde (S), vanillin $(\mathrm{V})$, syringic acid (SA), vanillic acid (VA), and $n$-alkanes are common biomass burning tracers and specific ratios of these compounds were suggested as indicators of peatland fire emissions in previous studies that analyzed the ambient air impacted by peat smoke (Fujii et al., 2014, 2015a, b). Some organic compounds (e.g., polycyclic aromatic hydrocarbons, PAHs) are highly enriched in peat smoke compared to raw peat biomass, showing over 100 times greater concentration in smoke than soil and indicating their formation during combustion (Black et al., 2016).

Prior studies of peat-burning emissions involved either laboratory experiments or collecting ambient aerosols at receptor sites impacted by peat smoke. Many of these studies primarily focused on chemically characterizing gaseous emissions (Benner, 1977; Chen et al., 2007; Christian et al., 2003; Geron and Hays, 2013; May et al., 2014; McMahon et al., 1980; Ward, 1990; Hatch et al., 2015; Stockwell et al., 2015, 2014; George et al., 2016; Black et al., 2016; Iinuma et al., 2007; Yokelson et al., 1997) while fewer focused on the PM fraction (Black et al., 2016; Fujii et al., 2014, 2015a; Iinuma et al., 2007). Peatland fire emissions were not considered in the biomass burning emission inventory published by Andreae and Merlet (2001). Akagi et al. (2011) updated this inventory to include peatland fires as a source of biomass burning emissions but did not report an $\mathrm{PM}_{2.5}$ emission factor $\left(\mathrm{EF}_{\mathrm{PM}_{2.5}}\right)$. Peat fire $\mathrm{EF}_{\mathrm{PM}_{2.5}}$ reported in the literature have varied by a large scale, ranging from 5.9 to $66 \mathrm{~g} \mathrm{~kg}^{-1}$ with uncertainties associated with measurements of emissions of black carbon (BC) and organic carbon (OC) greater than $50 \%$ of the associated value (Black et al., 2016; Geron and Hays, 2013; Akagi et al., 2011). Thus, the global estimates of peat fire $\mathrm{PM}_{2.5}, \mathrm{OC}$, and $\mathrm{BC}$ emissions are associated with large uncertainties. The variation across lab-measured emis- 
sion factors (EFs) likely results from different burning conditions. In addition, the dissection of peat soil during sampling, handling, transport, and storage of peat can significantly alter its physical properties and subsequent combustion. Thus, in situ sampling of peat fire emissions under natural burning conditions is needed to accurately represent peat fire emissions in global peat fire emission estimates and parameterize human exposure studies and climate and air quality models (Van der Werf et al., 2010; Page et al., 2002; Akagi et al., 2011).

The objectives of this paper are to characterize in situ peat PM emissions from different peat-burning sites in Indonesia during the 2015 El Niño period, compute PM emission factors and develop source profiles for peat-burning aerosols, and compare the peat PM emission factors from the literature with our in situ measurements. A moveable lab was deployed during the 2015 fire episode in Palangka Raya, Central Kalimantan, to make in situ ground-based measurements of trace gases and aerosols directly from authentic peatland fire smoke. Samples discussed in this paper were collected from 18 peat fire smoke plumes across 6 sites and were chemically speciated for $\sim 90$ gas-phase species and $\sim 70$ particulate-phase species. This paper focuses on the particulate-phase chemistry, and a comprehensive description of gas-phase emissions and optical properties (brown carbon $(\mathrm{BrC}), \mathrm{BC}$, and the mass absorption coefficients for the bulk OC due to BrC) is given in Stockwell et al. (2016). Combined together, EFs for more than 150 gaseous and particulate species were determined, providing a wealth of chemical detail on these emissions and enabling the evaluation of the magnitude of $\mathrm{PM}_{2.5}$ emissions and the ratio of particulate to gaseous carbon emitted from the $2015 \mathrm{El}$ Niño peat fires.

\section{Experimental details}

\subsection{Site description}

A comprehensive description of sampling sites is given in Stockwell et al. (2016) and a brief overview is given here. $\mathrm{PM}_{2.5}$ samples were collected from 18 separate plumes from 6 different peatland areas in Central Kalimantan, Indonesia, from 1 to 7 November during the 2015 El Niño. The sites were carefully selected to represent different peat types (fibric, hemic, or sapric) and cover a range of burning depths ranging from 18 to $62 \mathrm{~cm}$, averaging ( \pm standard deviation) $34 \pm 12 \mathrm{~cm}$. The sampled sites were located where the maximum fire activity is typically reported, in moderately to heavily disturbed areas by roads, canals, and/or previous fires. The aboveground vegetation was nonexistent (most often due to surface fires that ignited the peat hours to days prior to sampling) or limited to ferns or patchy secondary vegetation that was not burning. The samples were collected directly from visible plumes in smoldering peat. Sampling was im- mediately stopped during any occasional flaming combustion events within aboveground vegetation in the vicinity to ensure sampling of pure smoldering peat emissions.

Each plume was identified by an English letter (E-Z to AA) and the complete description of the plumes including peat type, burning depth, and surface fuel is given in Table S1 of Stockwell et al. (2016). Two PM samples were collected from plumes $\mathrm{E}, \mathrm{F}$, and $\mathrm{W}$, bringing the total number of PM samples to 21. Because of the variability in PM emissions within a single plume, both values were used in calculating study averages. Plume Y showed a different emission profile from the others likely due to co-burning of leaf litter at this shallow peat-burning site. Thus, plume $\mathrm{Y}$ was excluded from average calculations but individual values are reported in Table S2 and corresponding figures.

\subsection{Sample collection}

A comprehensive description of sample collection is given in Stockwell et al. (2016). In brief, $\mathrm{PM}_{2.5}$ was collected using a custom-built, two-channel PM sampler. The sampling inlet was mounted on a $\sim 2.5 \mathrm{~m}$ pole to allow sampling of smoke from a safe distance. The inlet was positioned approximately $2-3 \mathrm{~m}$ downwind of the smoldering peat, at a point where the plume of smoke had cooled to near-ambient temperature. The sample inlet was not fixed to a point and always followed the plume path when the plume direction changed due to variations in ambient air flow. PM samples were collected over a period of 9-30 min each, at $\mathrm{PM}_{2.5}$ concentrations that averaged $15 \mathrm{mg} \mathrm{m}^{-3}$ and ranged from 1 to $40 \mathrm{mg} \mathrm{m}^{-3}$. The duration of filter sample collection and $\mathrm{PM}_{2.5}$ concentrations sampled are summarized in Table S1 for each plume. For plumes with two samples collected, the time over which samples were collected were comparable and the sampled $\mathrm{PM}_{2.5}$ concentrations were within a factor of 3. The PM was collected on pre-cleaned $47 \mathrm{~mm}$ quartz fiber filters (QFFs) and pre-weighed Teflon filters (PALL, Life Sciences, Port Washington, NY) preceded by two $2.5 \mu \mathrm{m}$ sharp-cut cyclones (URG). The filtered air was then passed to the land-based Fourier transform infrared (LA-FTIR) spectrometer multipass cell for the measurement of gas-phase species as described by Stockwell et al. (2016). Sampled filters were stored in the dark and frozen $\left(-20^{\circ} \mathrm{C}\right)$ and were shipped frozen to the University of Iowa for chemical analysis.

Field blanks were collected for every fifth sample. For some samples a second (backup) QFF was placed in series behind the first (front) QFF in order to assess the positive sampling artifacts from carbonaceous gas adsorption. Filter samples were collected upwind of the plumes for $\sim 20 \mathrm{~min}$ (similar to smoke sampling duration) in order to account for background $\mathrm{PM}_{2.5}$. 


\subsection{PM $_{2.5}$ mass, elemental carbon (EC), and organic carbon measurement}

A complete description of PM mass, EC, and OC measurements is given in Stockwell et al. (2016). In brief, PM mass was calculated as the difference of pre- and post-sampling filter weights of Teflon filters after conditioning for $48 \mathrm{~h}$ in a desiccator. The relative error in the PM mass measurements was propagated from the standard deviation of the triplicate measurements of pre- and post-sampling filter weights, the standard deviation of background PM masses, and $10 \%$ of the PM mass concentration, which is a conservative estimate of the analytical uncertainty associated with the mass measurement. Ambient background $\mathrm{PM}_{2.5}$ concentrations were very similar across all the sites and on average the ambient $\mathrm{PM}_{2.5}$ contributed only $0.60 \%$ of the sampled $\mathrm{PM}_{2.5}$ mass, indicating that the ambient PM contribution was very small compared to PM concentration in the peat smoke. Nevertheless, the average background concentration was subtracted from the sample concentrations in order to calculate pure peat fire emissions.

EC and OC were measured by thermal optical analysis following the NIOSH 5040 method using $1.00 \mathrm{~cm}^{2}$ punches of QFFs (Sunset Laboratories, Forest Grove, OR) (NIOSH, 2003). The uncertainty in OC measurements was propagated from the standard deviation of the background filters, the standard deviation of the backup filters, and $10 \%$ of the OC concentration, a conservative estimate of the method precision in replicate measurements (NIOSH, 2003). The uncertainty of EC measurements was propagated from the instrumental uncertainty $\left(0.05 \mu \mathrm{g} \mathrm{cm}^{-2}\right), 5 \%$ of the measured EC, and $5 \%$ of pyrolyzed carbon, which refers to organic carbon that charred during analysis.

\subsection{Water-soluble organic carbon (WSOC)}

A $1.053 \mathrm{~cm}^{2}$ subsample of QFF was analyzed for WSOC using a total organic carbon analyzer (Sievers $5310 \mathrm{C}$, General Electric). WSOC was extracted into $15.0 \mathrm{~mL}$ of $>18.2 \mathrm{M} \Omega$ resistivity ultra-pure water (Thermo, Barnstead Easypure II) using acid washed $\left(10 \%\right.$ nitric acid) and pre-baked $\left(550^{\circ} \mathrm{C}\right.$ for $5.5 \mathrm{~h}$ ) glassware. Inorganic carbon was removed with an inorganic carbon remover (Sievers ICR, General Electric). WSOC was measured in triplicate and quantified using standard calibration curves prepared from potassium hydrogen phthalate (Ultra Scientific). The WSOC concentration in the sampled plumes was calculated using the extraction volume, total filter area, and sampled air volume. The uncertainty of the WSOC measurement was propagated using the standard deviation of the triplicate measurements, standard deviation of the background filters and $10 \%$ of the WSOC concentration. The fraction of water-insoluble organic carbon (WIOC) was calculated by subtracting the WSOC concentration from total OC concentration. The error of WIOC concentration was propagated from individual uncertainties of OC and WSOC.

\subsection{Water-soluble inorganic ions}

Water-soluble inorganic ions were quantified in aqueous extracts of Teflon filters by ion exchange chromatography coupled with conductivity detection as described in detail elsewhere (Jayarathne et al., 2014). In brief, half of the Teflon filter was uniformly wet with $50 \mu \mathrm{L}$ of isopropyl alcohol and subsequently extracted into $15.0 \mathrm{~mL}$ ultra-pure water ( $>18.2 \mathrm{M} \Omega$ resistivity) by shaking $12 \mathrm{~h}$ at $125 \mathrm{rpm}$. For cation analysis, a Dionex IonPac CS12A column was used with the mobile phase of $20 \mathrm{mM}$ methane sulfonic acid at $0.5 \mathrm{~mL} \mathrm{~min}^{-1}$ flow rate. A Dionex IonPac AS22 anion column with the mobile phase of $4.5 \mathrm{mM}$ sodium carbonate $\left(\mathrm{Na}_{2} \mathrm{CO}_{3}\right)$ and $1.4 \mathrm{mM}$ sodium bicarbonate $\left(\mathrm{NaHCO}_{3}\right)$ at a flow rate of $1.2 \mathrm{~mL} \mathrm{~min}^{-1}$ was used for anion separation. A conductivity detector (Thermo) was used for detection and was preceded by a self-regenerating suppressor: CERS-500 and AERS-500 for cations and anions, respectively.

\subsection{Total metals}

Teflon filters were cut in half using ceramic blades and then digested in mixtures of 2:1 concentrated nitric and hydrochloric acid (TraceMetal Grade, Fisher Chemical) using a MARS 6 microwave-assisted digestion system (CEM Corporation, Matthews, NC) at $200^{\circ} \mathrm{C}$ for 13 min following US EPA method 3052 (USEPA, 1995). Extracts were filtered $(0.45 \mu \mathrm{m}$ PTFE $)$ and analyzed for metals using a Thermo $\mathrm{X}$-Series II quadrupole ICP-MS instrument (Thermo Fisher Scientific Inc., Waltham, MA, USA) (Peate et al., 2010). The instrument was calibrated against IV-ICPMS-71A ICP-MS standard (Inorganic Ventures) at concentrations ranging from 0.1 to $50 \mathrm{ppb}$. The metal concentration in the extract was converted to metal oxide concentration in the sampled plumes $\left(\mu \mathrm{g} \mathrm{m}^{-3}\right)$ using extraction volume, total filter area, sampled air volume, metal to metal oxide mass ratio, and the natural metal isotope abundance (Rosman and Taylor, 1999). The uncertainty of the measurement was propagated using the method detection limits, standard deviation of the field blank filters, and $10 \%$ of the metal concentration.

\subsection{Organic species}

Organic species were quantified in organic extracts of QFF by gas chromatography coupled to mass spectrometry (GCMS) as described in detail elsewhere (Al-Naiema et al., 2015). In brief, QFFs were subsampled to obtain $\sim 200 \mu \mathrm{g} \mathrm{C}$ prior to organic species characterization. These subsamples were spiked with deuterated internal standards which were used in quantification: pyrene- $\mathrm{D}_{10}$, benz(a)anthracene- $\mathrm{D}_{12}$, cholestane- $\mathrm{D}_{4}$, pentadecane- $\mathrm{D}_{32}$, eicosane- $\mathrm{D}_{42}$, tetracosane$\mathrm{D}_{50}$, triacontane- $\mathrm{D}_{62}$, dotriacontane- $\mathrm{D}_{66}$, hexatriacontane$\mathrm{D}_{74}$, levoglucosan- ${ }^{13} \mathrm{C}_{6}$, and cholesterol- $\mathrm{D}_{6}$. Each subsam- 
ple was then stepwise extracted in $2 \times 20 \mathrm{~mL}$ aliquots of hexane followed by $2 \times 20 \mathrm{~mL}$ aliquots of acetone by ultrasonication (60 sonics $\mathrm{min}^{-1}, 5510$-Branson) for $15 \mathrm{~min}$. The solvent extracts were subsequently concentrated to a final volume of $\sim 100 \mu \mathrm{L}$ using Turbovap (Caliper Life Sciences, Turbo Vap LV Evaporator) and micro-scale nitrogen evaporation system (Thermo Scientific, Reacti-Vap ${ }^{\mathrm{TM}}$ Evaporator) upon high-purity nitrogen (PRAXAIR Inc.). These extracted samples were stored at $-20^{\circ} \mathrm{C}$ until chemical analysis.

Organic species in filter extracts were quantified using GC-MS (Agilent Technologies GC-MS 7890A) equipped with an Agilent DB-5 column $(30 \mathrm{~m} \times 0.25 \mathrm{~mm} \times 0.25 \mu \mathrm{m})$ with electron ionization source using a temperature program ranging from 60 to $300^{\circ} \mathrm{C}$. Helium was utilized as the carrier gas, and $3 \mu \mathrm{L}$ aliquots of the extracts were injected in splitless mode. Oxygenated compounds were analyzed following trimethylsilyl derivatization (Stone et al., 2012). Briefly, $10 \mu \mathrm{L}$ of the extract was blown down to complete dryness and reconstituted in $10 \mu \mathrm{L}$ of pyridine (Burdick \& Jackson, Anhydrous). A $20 \mu \mathrm{L}$ of the silylation agent N,O-bis(trimethylsilyl)trifluoroacetamide (Fluka Analytical, 99\%) was added to the mixture and was heated for $3 \mathrm{~h}$ at $70^{\circ} \mathrm{C}$ to complete the silylation reaction. The silylated samples were immediately analyzed.

Responses of analytes were normalized to the corresponding isotopically labeled internal standard and five-point linear calibration curves (with correlation coefficients, $R^{2} \geq 0.995$ ) were utilized for the quantification of organic species. Compounds that were not in the standards were measured by assessing the response curve from the compound that was most analogous in structure and retention time. The analyte concentration in the extract was converted to ambient concentrations $\left(\mu \mathrm{g} \mathrm{m}^{-3}\right.$ ) using extraction volume, the total filter area, and sampled air volume. The analytical uncertainties for the measured species were propagated from the method detection limits, standard deviation of the field blank filters, and $20 \%$ of the measured concentration, which is based upon the spike recoveries of individual species being allowed to vary within $100 \pm 20 \%$.

\subsection{Emission factor calculation}

The mixing ratios of $\mathrm{CO}_{2}, \mathrm{CO}, \mathrm{CH}_{4}$, and $\sim 90$ other gases were quantified by a field-deployed FTIR spectrometer combined with whole air sampling (Stockwell et al., 2016). The carbon mass balance approach was used to determine fuelbased EFs for gases, in units of mass of analyte per kilogram of fuel burned $\left(\mathrm{g} \mathrm{kg}^{-1}\right)$ (Stockwell et al., 2016). Carbon monoxide was used as the reference species to calculate the EFs of particulate species. For this purpose, carbon monoxide mass drawn through the filter $\left(M_{\mathrm{CO}}\right)$ that was measured in series by FTIR, the mass of the analyte $\left(M_{\mathrm{X}}\right.$; i.e., PM mass, EC, OC), and emission factor of carbon monoxide $\left(\mathrm{EF}_{\mathrm{CO}}\right)$ were used to calculate the emission factors of the desired analyte $\left(\mathrm{EF}_{\mathrm{X}}\right)$ using Eq.(1).

$\mathrm{EF}_{\mathrm{X}}=\frac{M_{\mathrm{X}}}{M_{\mathrm{CO}}} \times \mathrm{EF}_{\mathrm{CO}}$

Uncertainty in $\mathrm{EF}_{\mathrm{X}}$ was propagated from the relative uncertainty of $\mathrm{EF}_{\mathrm{CO}}$, conservatively estimated as $5 \%$ of the value and the analytical uncertainty of the considered analyte.

\subsection{Modified combustion efficiency (MCE)}

MCE was calculated as $\mathrm{MCE}=\Delta \mathrm{CO}_{2} /\left(\Delta \mathrm{CO}+\Delta \mathrm{CO}_{2}\right)$ and was used as an indicator of predominantly flaming combustion (MCE > 0.9) and smoldering combustion $(\sim 0.72-0.84)$ (Yokelson et al., 1996). Notably, the filter-integrated MCE values reported herein correspond to the duration of filter sample collection and could differ slightly from those reported by Stockwell et al. (2016) that were interjected, unfiltered samples of the same plumes.

\section{Results and discussion}

\subsection{Emission of $\mathbf{P M}_{2.5}$}

$\mathrm{EF}_{\mathrm{PM}_{2.5}}$ for in situ Indonesian peat burning ranged from 6.04 to $29.6 \mathrm{~g} \mathrm{~kg}^{-1}$ for 18 plumes, averaging ( \pm standard deviation) $17.3 \pm 6.0 \mathrm{~g} \mathrm{~kg}^{-1}$ (Fig. 1). The percent difference across samples collected sequentially from the same plume was 57 , 37 , and $8 \%$ for plumes $\mathrm{E}, \mathrm{F}$, and $\mathrm{W}$, respectively, indicating some temporal variability in emissions within the fire as it progresses. This in-plume variability in the field could result from the spread and progression of the fire, consistent with peat samples burned batch-wise in laboratory settings that show $\mathrm{EF}_{\mathrm{PM}_{2.5}}$ decreases on the timescale of hours during combustion (Black et al., 2016). The overall relative standard deviation of $\mathrm{EF}_{\mathrm{PM}_{2.5}}$ in this study was $35 \%$, indicating that variability across plumes is on the same order as in-plume variability.

The average $\mathrm{EF}_{\mathrm{PM}_{2.5}}$ for Indonesian peat burning is within the range of values reported in prior laboratory studies (6$66 \mathrm{~g} \mathrm{~kg}^{-1}$; Table 1). Generally, the variability is attributed to natural variation within the fuel (including its chemical composition (e.g., C content), moisture content, and fuel density) and burn conditions (e.g., extent of flaming versus smoldering combustion) (Iinuma et al., 2007). The average $\mathrm{EF}_{\mathrm{PM}_{2.5}}$ reported by Black et al. (2016) for two samples of North Carolina peat $\left(7.1 \pm 5.6\right.$ and $\left.5.9 \pm 6.7 \mathrm{~g} \mathrm{~kg}^{-1}\right)$ are in the lower range of $\mathrm{EF}_{\mathrm{PM}_{2.5}}$ observed in this study. The peat fires studied by Black et al. (2016) exhibited higher MCE values (0.80-0.88) compared to this study (0.73-0.83), in which the former corresponds to lower PM emissions (McMeeking et al., 2009) and may have resulted from oven-drying their peat samples prior to combustion. Meanwhile, the observed $\mathrm{EF}_{\mathrm{PM}_{2.5}}$ value for in situ Indonesian peat burning is lower 
Table 1. Comparison of the averaged in situ Indonesian peat emission data to prior laboratory studies of peat combustion.

\begin{tabular}{|c|c|c|c|c|c|c|c|c|c|}
\hline $\begin{array}{l}\text { Peat location } \\
\text { of origin (and type) }\end{array}$ & $\begin{array}{l}\text { PM } \\
\text { Size }\end{array}$ & $\begin{array}{r}\text { No. of } \\
\text { samples }\end{array}$ & $\begin{array}{r}\mathrm{EF} P M \\
\left(\mathrm{~g} \mathrm{~kg}^{-1}\right)\end{array}$ & $\begin{array}{r}\text { OC } \\
(\%) \text { Mass }\end{array}$ & $\begin{array}{r}\text { EC } \\
(\% \text { Mass })\end{array}$ & $\begin{array}{r}\text { WSOC \% } \\
\text { of OC }\end{array}$ & $\mathrm{OC}: \mathrm{EC}$ & MCE & Reference \\
\hline Indonesia & $\mathrm{PM}_{2.5}$ & 21 & 17 & 72 & 1.1 & 16 & 60 & 0.78 & This study \\
\hline Indonesia & $\mathrm{PM}_{2.5}$ & 1 & $6.06^{\mathrm{a}}$ & $99^{\mathrm{a}}$ & $1^{\mathrm{a}}$ & - & 151 & 0.838 & Christian et al. (2003) \\
\hline Indonesia & $\mathrm{PM}_{1}$ & 1 & 34.9 & $99^{\mathrm{b}}$ & $0.03^{\mathrm{c}}$ & - & - & 0.891 & May et al. (2014) \\
\hline Indonesia & $\mathrm{PM}_{10}$ & 1 & 33 & 24 & 1.7 & 39 & 14 & - & Iinuma et al. (2007) \\
\hline German & $\mathrm{PM}_{10}$ & 1 & 44 & 29 & 2.2 & 52 & 13 & - & Iinuma et al. (2007) \\
\hline North Carolina (ARNWR) ${ }^{\mathrm{d}}$ & $\mathrm{PM}_{2.5}$ & 4 & 7.1 & 89 & 0.73 & - & 122 & 0.89 & Black et al. (2016) \\
\hline North Carolina (PLNWR) ${ }^{\mathrm{e}}$ & $\mathrm{PM}_{2.5}$ & 4 & 5.9 & 73 & 1.4 & - & 52 & 0.88 & Black et al. (2016) \\
\hline North Carolina (ARNWR) ${ }^{\mathrm{d}}$ & $\mathrm{PM}_{2.5}$ & 4 & $48-66$ & - & - & - & - & $0.79-0.86$ & Geron and Hays (2013) \\
\hline North Carolina (PLNWR) ${ }^{\mathrm{e}}$ & $\mathrm{PM}_{2.5}$ & 4 & $35-55$ & - & - & - & - & $0.77-0.83$ & Geron and Hays (2013) \\
\hline North Carolina (Green Swamp) & $\mathrm{PM}_{2.5}$ & 4 & $44-53$ & - & - & - & - & $0.80-0.81$ & Geron and Hays (2013) \\
\hline Florida (sawgrass) ${ }^{\mathrm{f}}$ & $\mathrm{PM}_{2.5}$ & 6 & 30 & - & - & - & - & - & McMahon et al. (1980) \\
\hline Alaska (tundra core) & TSP & - & 41.3 & 93.5 & 2.6 & - & 36 & 0.87 & Chen et al. (2007) \\
\hline
\end{tabular}

${ }^{\mathrm{a}}$ PM mass was not directly measured and was estimated as the sum of EC and OC. ${ }^{\mathrm{b}}$ Measured as organic aerosol. ${ }^{\mathrm{c}}$ Measured as refractory black carbon. ${ }^{\mathrm{d}}$ Alligator River National Wildlife Refuge. e Pocosin Lakes National Wildlife Refuge. ${ }^{\mathrm{f}}$ Corresponds to dry peat within the first $24 \mathrm{~h}$ of combustion.

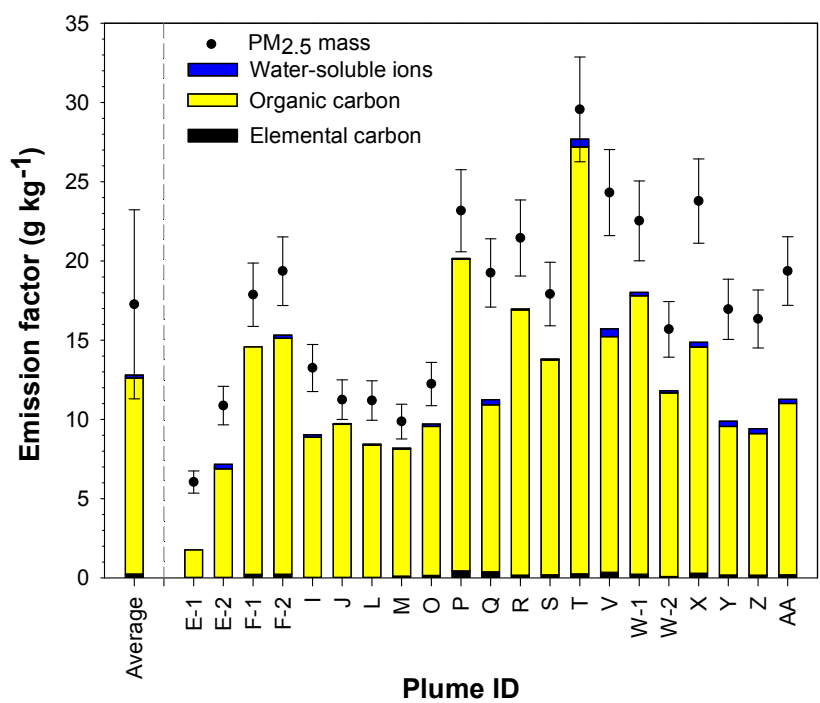

Figure 1. Emission factors of $\mathrm{PM}_{2.5}, \mathrm{EC}, \mathrm{OC}$, and water-soluble ions for the average and individual peat smoke plumes. Error bars represent 1 standard deviation of the average or the propagated analytical uncertainty. $\mathrm{EF}_{\mathrm{PM}_{2.5}}$ was dominated by OC (72\%) with minor contributions from $\mathrm{EC}(<1 \%)$, ions $(<1 \%)$, and metal oxides $(<0.15 \%$, not shown).

than the $\mathrm{EF}_{\mathrm{PM}_{2.5}}$ values reported by other laboratory studies: $46 \pm 21 \mathrm{~g} \mathrm{~kg}^{-1}$ by Geron and Hays (2013), 33-44 $\mathrm{g} \mathrm{kg}^{-1}$ (for $\mathrm{PM}_{10}$ ) by Iinuma et al. (2007), $42 \mathrm{~g} \mathrm{~kg}^{-1}$ by Chen et al. (2007), $35 \mathrm{~g} \mathrm{~kg}^{-1}$ by May et al. (2014), and $30 \pm 20 \mathrm{~g} \mathrm{~kg}^{-1}$ by McMahon et al. (1980). These higher $\mathrm{EF}_{\mathrm{PM}_{2.5}}$ could be due to natural variability in the peat composition and/or experimental variables such as sampling from early stage of fires or extent of dilution. We also cannot rule out that the smoke in some previous laboratory studies was concentrated enough to increase gas-particle partitioning beyond the level in our samples. Further, alterations to peat between the field and laboratory may have an effect through the transporting and handling of peat soils, differences associated with igniting the peat sample (e.g., heated coil vs. propane torch), the edge effects due to igniting small chunks of peat, and sustainability of the fire during the time of sample collection could also affect the $\mathrm{EF}_{\mathrm{PM}_{2.5}}$. Because the $\mathrm{EF}_{\mathrm{PM}_{2.5}}$ computed during this study corresponds to natural conditions of peat burning that was not handled, transported, or processed disturbing the peat soil micro-properties, the reported measurements are not subject to potential fuel alteration.

\subsection{Emission of OC, EC, and WSOC}

Across the studied plumes, $\mathrm{EF}_{\mathrm{OC}}$ ranged from 1.76 to $26.9 \mathrm{~g} \mathrm{~kg}^{-1}$, averaging $12.4 \pm 5.4 \mathrm{~g} \mathrm{~kg}^{-1}$ (Fig. 1). The high OC mass fraction of PM $(72 \pm 11 \%)$ is in a good agreement with literature reported values of $73-89 \%$ by Black et al. (2016) and $94 \%$ by Chen et al. (2007) for $\mathrm{PM}_{2.5}$ from peat combustion in laboratory studies. The $\mathrm{EF}_{\mathrm{EC}}$ ranged from 0.09 to $0.44 \mathrm{~g} \mathrm{~kg}^{-1}$, averaging $0.24 \pm 0.10 \mathrm{~g} \mathrm{~kg}^{-1}$ (Table 2). The high $\mathrm{EF}_{\mathrm{OC}}$ and low $\mathrm{EF}_{\mathrm{EC}}$ values are consistent with purely smoldering combustion with MCE values of 0.7250.833 as discussed by Stockwell et al. (2016). The optically measured $\mathrm{EF}_{\mathrm{BC}}$ in $\mathrm{PM}_{1}$ by photoacoustic extinctiometry (PAX) $\left(0.006 \pm 0.002 \mathrm{~g} \mathrm{~kg}^{-1}\right)$ was noticeably lower than that of filter-based $\mathrm{EF}_{\mathrm{EC}}$ likely due to sampling of char particles by filters, different PM size cuts, and differences in measurement methods (Stockwell et al., 2016). Overall, both optical and chemical measurement methods employed in Indonesia and prior studies of EC in peat-burning emissions (Table 1) agree that $\mathrm{EF}_{\mathrm{EC}}$ and $\mathrm{EF}_{\mathrm{BC}}$ are very small compared to $\mathrm{EF}_{\mathrm{OC}}$.

The OC : EC ratio for in situ Indonesian peat burning ranged from 27 to 129 , averaging $67 \pm 26$. This is in the middle of the range of OC : EC values reported previously for peat combustion (Table 1). The PAX results showed that the ratio of light absorption at $405 \mathrm{~nm}$ relative to $870 \mathrm{~nm}$ wavelength was approximately 50 (Stockwell et al., 2016), whereas a ratio close to 2.2 is indicative of absorption by 
Table 2. Average emission factors for $\mathrm{PM}_{2.5}$, EC, OC, watersoluble ions, metals (as mass fraction of $\mathrm{PM}_{2.5}$ ), and organic species normalized to organic carbon mass. Individual EF data are given in Table $\mathrm{S} 2$.

\begin{tabular}{|c|c|c|}
\hline Species & $\begin{array}{r}\text { Study } \\
\text { average }\end{array}$ & $\begin{array}{l}\text { Standard } \\
\text { deviation }\end{array}$ \\
\hline $\mathrm{EF} \mathrm{PM}_{2.5}\left(\mathrm{~g} \mathrm{~kg}^{-1}\right)$ & 17.3 & 6.0 \\
\hline $\mathrm{EC}$ (as mass fraction of $\mathrm{PM}_{2.5} ; \mathrm{g} \mathrm{gPM}_{2.5}^{-1}$ ) & 0.011 & 0.005 \\
\hline $\mathrm{OC}$ (as mass fraction of $\mathrm{PM}_{2.5} ; \mathrm{g} \mathrm{gPM}_{2.5}^{-1}$ ) & 0.72 & 0.11 \\
\hline Water-soluble OC fraction & 0.16 & 0.11 \\
\hline Water-insoluble OC fraction & 0.84 & 0.11 \\
\hline \multicolumn{3}{|c|}{ Water-soluble ions (as mass fraction of $\mathrm{PM}_{2.5} ; \mathrm{mg} \mathrm{gPM}_{2.5}^{-1}$ ) } \\
\hline Sodium & 0.054 & 0.065 \\
\hline Ammonium & 5.1 & 3.0 \\
\hline Potassium & 0.26 & 0.43 \\
\hline Fluoride & 0.66 & 0.63 \\
\hline Chloride & 4.2 & 2.4 \\
\hline Nitrate & 0.16 & 0.13 \\
\hline Sulfate & 1.41 & 1.42 \\
\hline \multicolumn{3}{|l|}{ Metals (as mass fraction of $\mathrm{PM}_{2.5} ; \mathrm{mg} \mathrm{gPM}_{2.5}^{-1}$ ) } \\
\hline $\mathrm{Fe}$ & 0.27 & 0.10 \\
\hline $\mathrm{Cu}$ & 0.74 & NA \\
\hline $\mathrm{Zn}$ & 0.40 & NA \\
\hline As & 0.007 & 0.002 \\
\hline $\mathrm{Cd}$ & 0.0002 & 0.0001 \\
\hline $\mathrm{Ba}$ & 0.014 & 0.010 \\
\hline $\mathrm{Pb}$ & 0.04 & NA \\
\hline \multicolumn{3}{|c|}{$\begin{array}{l}\text { Organic species (as mass fraction of organic carbon; } \mathrm{mg} \mathrm{gOC}^{-1} \text { ) } \\
\text { PAHs }\end{array}$} \\
\hline Anthracene & 0.0062 & 0.0036 \\
\hline Fluoranthene & 0.036 & 0.017 \\
\hline Pyrene & 0.056 & 0.031 \\
\hline Methylfluoranthene & 0.043 & 0.021 \\
\hline Benzo(ghi)fluoranthene & 0.0056 & 0.0029 \\
\hline Cyclopenta(cd)pyrene & 0.0045 & 0.0022 \\
\hline Benz(a)anthracene & 0.023 & 0.013 \\
\hline Chrysene & 0.054 & 0.021 \\
\hline 1-Methylchrysene & 0.019 & 0.010 \\
\hline Retene & 0.031 & 0.028 \\
\hline Benzo(b)fluoranthene & 0.023 & 0.013 \\
\hline Benzo(k)fluoranthene & 0.0036 & 0.0028 \\
\hline Benzo(j)fluoranthene & 0.0031 & 0.0023 \\
\hline Benzo(e)pyrene & 0.029 & 0.016 \\
\hline Benzo(a)pyrene & 0.0081 & 0.0066 \\
\hline Perylene & 0.0041 & 0.0034 \\
\hline Benzo(ghi)perylene & 0.016 & 0.011 \\
\hline Dibenz(ah)anthracene & 0.0098 & 0.0085 \\
\hline Picene & 0.0139 & 0.0051 \\
\hline \multicolumn{3}{|l|}{ Hopanes } \\
\hline $17 \alpha(\mathrm{H})-22,29,30$-Trisnorhopane & 0.344 & 0.058 \\
\hline $17 \beta(\mathrm{H})-21 \alpha(\mathrm{H})-30$-Norhopane & 0.85 & 0.13 \\
\hline $17 \alpha(\mathrm{H})-21 \beta(\mathrm{H})$-Hopane & 0.218 & 0.066 \\
\hline
\end{tabular}

NA indicates not applicable, as the analyte was detected in two or fewer samples.
Table 2. Continued.

\begin{tabular}{|c|c|c|}
\hline Species & $\begin{array}{r}\text { Study } \\
\text { average }\end{array}$ & $\begin{array}{l}\text { Standard } \\
\text { deviation }\end{array}$ \\
\hline \multicolumn{3}{|l|}{$n$-Alkanes } \\
\hline Octadecane & 0.39 & 0.46 \\
\hline Nonadecane & 1.1 & 1.3 \\
\hline Eicosane & 2.2 & 2.2 \\
\hline Heneicosane & 3.8 & 2.8 \\
\hline Docosane & 4.3 & 3.2 \\
\hline Tricosane & 4.8 & 2.1 \\
\hline Tetracosane & 4.1 & 2.2 \\
\hline Pentacosane & 5.4 & 2.4 \\
\hline Hexacosane & 4.1 & 2.1 \\
\hline Heptacosane & 5.5 & 2.2 \\
\hline Octacosane & 4.8 & 2.0 \\
\hline Nonacosane & 6.5 & 1.9 \\
\hline Triacontane & 4.7 & 1.4 \\
\hline Hentriacontane & 6.7 & 1.4 \\
\hline Dotriacontane & 3.03 & 0.52 \\
\hline Tritriacontane & 2.83 & 0.54 \\
\hline Tetratriacontane & 1.25 & 0.23 \\
\hline Pentatriacontane & 0.66 & 0.15 \\
\hline Heptatriacontane & 0.82 & 0.26 \\
\hline Octriacontane & 2.5 & 1.3 \\
\hline Nonatriacontane & 0.98 & 0.47 \\
\hline \multicolumn{3}{|l|}{ Branched alkanes } \\
\hline Norpristane & 0.35 & 0.47 \\
\hline Pristane & 1.0 & 1.2 \\
\hline Squalane & 1.31 & 0.74 \\
\hline \multicolumn{3}{|l|}{ Anhydrosugars } \\
\hline Levoglucosan & 46 & 40 \\
\hline Mannosan & 0.93 & 0.76 \\
\hline Galactosan & 0.14 & 0.13 \\
\hline \multicolumn{3}{|c|}{ Lignin decomposition products } \\
\hline Vanillin & 0.030 & 0.044 \\
\hline Syringaldehyde & 0.93 & 0.46 \\
\hline Vanillic acid & 3.7 & 2.2 \\
\hline Syringic acid & 1.69 & 0.91 \\
\hline \multicolumn{3}{|l|}{ Sterols } \\
\hline Stigmasterol & 0.22 & 0.11 \\
\hline$\beta$-Sitosterol & 0.53 & 0.34 \\
\hline Campesterol & 0.29 & 0.20 \\
\hline
\end{tabular}

pure BC (Bond and Bergstrom, 2006). Thus, the light absorption by peat smoke is largely due to $\mathrm{BrC}$ and the measured high $\mathrm{BrC}: \mathrm{BC}$ absorption ratio (52) is similar to the measured OC : EC ratio (Stockwell et al., 2016). The bright yellow color of the PM collected filters (Fig. S1) is also an indication of the light-absorbing nature of the $\mathrm{OC}$ and a very small relative emission of EC.

The prior lack of information on light absorption by peatburning emissions could potentially limit the accuracy of direct radiative forcing estimates in Southeast Asia (Ge et al., 


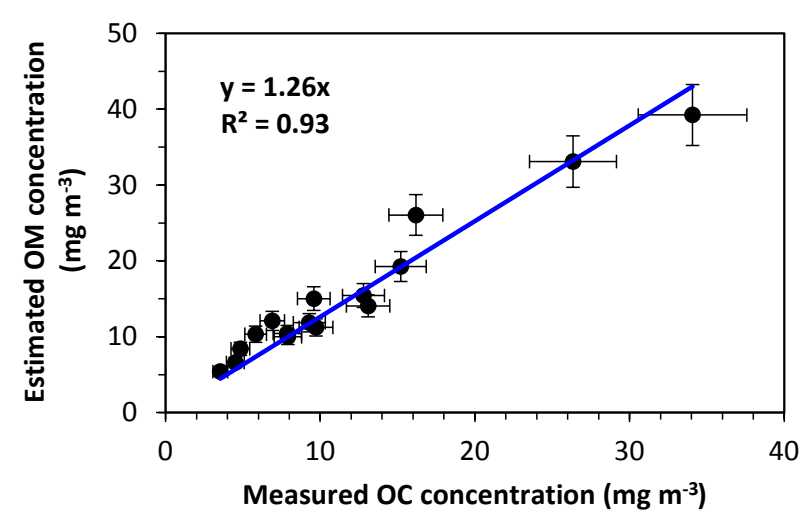

Figure 2. Linear regression of the measured organic carbon (OC) concentration versus the estimated organic matter (OM) concentration in sampled plumes that was calculated as the difference between $\mathrm{PM}_{2.5}$ mass and the sum of EC, water-soluble ions, and metal oxides.

2014). Previously, Ge et al. (2014) modeled radiative forcing using OC : EC values up to 17. Our much larger OC : EC values could imply that a more strongly scattering aerosol is relevant, depending on the extent to which regional emissions are dominated by peat burning. In addition, with new measurements of $\mathrm{BrC}$ presented in our companion paper (Stockwell et al., 2016), the role of $\mathrm{BrC}$ in direct radiative forcing should be evaluated in future assessments of this kind.

On average, only a minor fraction of OC was water soluble $(16 \pm 11 \%)$ and the majority $(84 \pm 11 \%)$ was water insoluble (Table 2). Hence, the majority of OC is composed of hydrophobic organic compounds. These results are consistent with prior observations of high relative concentrations of aliphatic organic species in peat and peat-burning aerosol reported previously (Iinuma et al., 2007; McMahon et al., 1980). The low water solubility and presence of hydrophobic organic species likely contribute to the hydrophobicity and low cloud condensation nuclei activity of fresh peat-burning emissions (Dusek et al., 2005).

\subsection{Chemical composition of $\mathbf{P M}_{2.5}$}

OC accounted for the major fraction of $\mathrm{PM}_{2.5}(72 \pm 11 \%)$ while EC was detected in only 15 plumes and on average comprised $1.2 \%$ of $\mathrm{PM}_{2.5}$ (Table 1). Minor contributions to $\mathrm{PM}_{2.5}$ were observed for water-soluble ions (1.2\%), and metal oxides (less than $0.1 \%$ ) (Table 2). The sum of OC, EC, water-soluble ions, and metal oxide masses comprised, on average, $74 \pm 11 \%$ of gravimetrically measured $\mathrm{PM}_{2.5}$ mass.

The remaining $\mathrm{PM}_{2.5}$ mass is expected to be primarily from elements associated with carbon in forming OM (e.g., $\mathrm{O}, \mathrm{H}, \mathrm{N}$ ). Assuming that no major chemical species were unmeasured, we estimate $\mathrm{OM}$ as the difference between $\mathrm{PM}_{2.5}$ mass and the sum of EC, water-soluble ions, and metal oxides $\left(\mathrm{OM}=\mathrm{PM}_{2.5}-[\mathrm{EC}+\right.$ ions + metals oxides $\left.]\right)$. The linear regression analysis of this estimate of $\mathrm{OM}$ and measured OC correlated strongly $\left(R^{2}=0.93\right)$, indicating their dependent co-variance (Fig. 2). The slope of the regression line is $1.26 \pm 0.04 \mathrm{OM} \mathrm{OC}^{-1}$ and provides the conversion factor of $\mathrm{OC}$ to $\mathrm{OM}$ for fresh peat-burning aerosols. This $\mathrm{OC}$ to $\mathrm{OM}$ factor is in the range of values typically observed for gasoline combustion (1.1-1.3) (Schauer et al., 2002, 1999) and below those used for other types of biomass burning (1.4 1.8) (Reid et al., 2005), which is expected to result from the semi-fossilized nature of the peat fuel and the waterinsoluble (Sect. 3.2) and aliphatic-rich (Sect. 3.5) nature of OC.

\subsection{MCE}

The calculated MCEs were indicative of smoldering combustions with values ranging $0.725-0.833$ (average $=0.78 \pm$ 0.04) (Yokelson et al., 1996). Burn depth and MCE were negatively correlated $(r=-0.738 ; p=0.001 ;$ Fig. S2), consistent with higher emission of $\mathrm{CO}_{(\mathrm{g})}$ relative to $\mathrm{CO}_{2(\mathrm{~g})}$ for deep peat combustion, potentially due to less oxygen supply. Over the small range of observed MCEs and for the purely smoldering combustion, neither MCE nor burn depth were correlated with PM mass, EC, or OC emission factors $(p>0.23)$ and thus did not noticeably affect PM emissions.

\subsection{Organic species}

A subset of samples $(n=10)$, representing at least one sample per sample collection site, was analyzed for anhydrosugars, lignin decomposition compounds, alkanes, hopanes, PAHs, and sterols. On average, the quantified organic compounds accounted for $\sim 9 \%$ of the total OC mass on a carbon basis with major contribution from alkanes $(6.2 \%)$, followed by anhydrosugars $(2.1 \%)$, lignin decomposition products $(0.36 \%)$, hopanes $(0.12 \%)$, sterols $(0.06 \%)$, and PAHs $(0.03 \%$ ) (Fig. 3). Up to approximately $5 \%$ more of the OC is expected to come from $n$-alkenes, some oxy$\mathrm{PAH}$, additional lignin decomposition products, and nitrophenols that were measured in peat emissions by Iinuma et al. (2007). The remaining OC remains unresolved and is likely to include isomers of the abovementioned compounds (e.g., branched alkanes) and high-molecular weight organic compounds. Plume $\mathrm{Y}$ that was obtained from shallow peatburning sites with plant roots observed in the burn pit had a different emission profile with a larger contribution from anhydrosugars $(16 \%)$ compared to lignin decomposition products $(2.8 \%)$ and alkanes $(1.6 \%)$. Plume Y thus represents the co-burning of peat with surface vegetation and was excluded from average calculations that represent subsurface burning of peat. The full emission profile for each individual plume is reported in Table $\mathbf{S} 2$. 


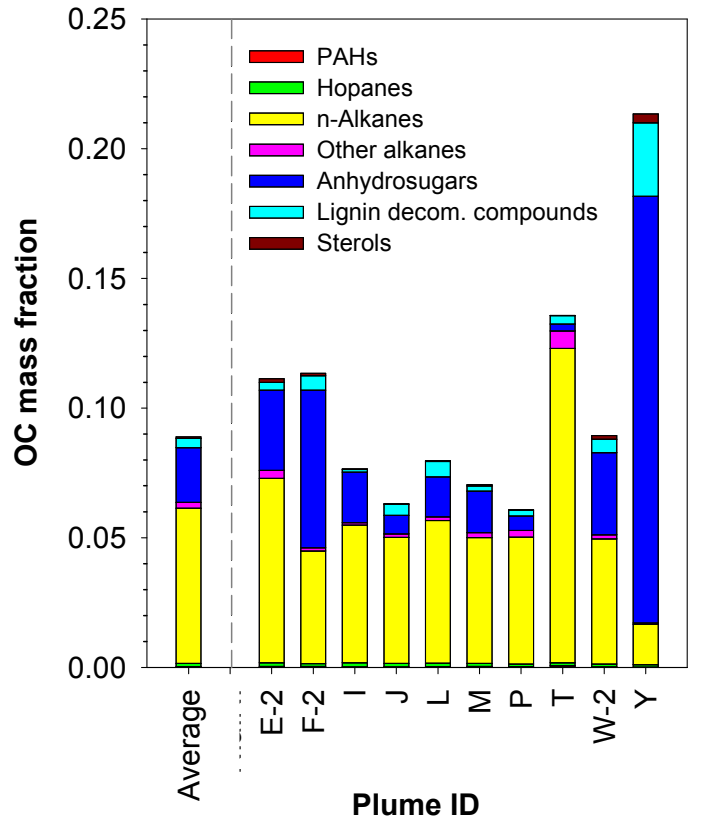

Figure 3. Organic carbon mass fraction of the speciated compound classes in selected peat-burning emission samples. Plume Y was excluded from the average calculation as discussed in Sect. 2.1.

\subsubsection{Alkanes}

The homologous series of $n$-alkanes and select branched alkanes were quantified in emissions from Indonesian peat burning. The $n$-alkanes with carbon numbers ranging $\mathrm{C}_{18}$ $\mathrm{C}_{34}$ were detected in all samples analyzed by GC-MS, with higher-carbon number homologues observed in many samples (Table S2). The $n$-alkane emission factor $\left(\mathrm{EF}_{\text {alk }}\right)$ for the quantified species ranged $456-3834 \mathrm{mg} \mathrm{kg}^{-1}$ (Table S2).

On average, $n$-alkanes contributed $6.2 \%$ of OC mass. This OC mass fraction is consistent with results from linuma et al. (2007) for Indonesian and German peat burning and is remarkably higher than other types of biomass burning $\mathrm{OC}$ for which this OC fraction is typically less than $1 \%$ (Hays et al., 2002; Iinuma et al., 2007). The high $n$-alkane contribution to OC results from the high lipid content of peat that accumulates from plant waxes (e.g., cutin, suberin) during decomposition (Ficken et al., 1998). The in situ source emissions and prior measurements of peat combustion in the field (Fujii et al., 2015a) and in the laboratory (Iinuma et al., 2007) agree that $n$-alkanes can be used to distinguish peat emissions from other types of biomass burning and other combustion sources by their high contribution to particle-phase OC.

The most abundant $n$-alkane $\left(\mathrm{C}_{\max }\right)$ was consistently observed for the $\mathrm{C}_{31}$ carbon homolog (Table S2). This is the same $C_{\max }$ value observed by Iinuma et al. (2007) for Indonesian peat, while in ambient air impacted by Indonesian peat burning, Fujii et al. (2015a) and bin Abas et al. (2004) reported $C_{\max }$ at $C_{27}$. This variability in $C_{\max }$ likely derives

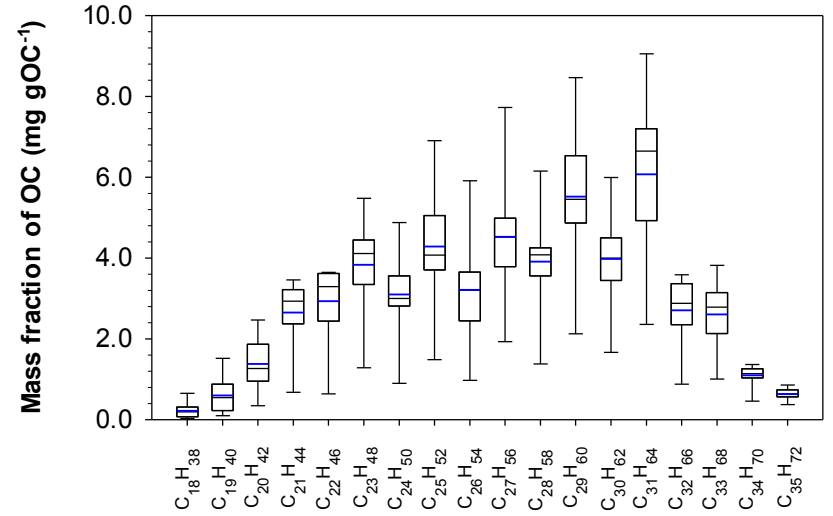

n-Alkane

Figure 4. Molecular distribution of $n$-alkanes for selected plumes $(n=10) . Y$ axis indicates individual $n$-alkane mass fraction of OC. The horizontal lines (black) in the box represent the 25th, 50th (median), and 75th percentiles and mean values are indicated by the blue lines.

from in the peat material but may be influenced by atmospheric aging as the differences in $\mathrm{C}_{\max }$ are aligned with fresh and aged peat-burning aerosol.

As shown in Fig. 4, $n$-alkanes demonstrated a slight odd carbon preference that is indicative of biogenic material, particularly plant waxes (Fine et al., 2002; Oros and Simoneit, 2001a, b; Baker, 1982). The carbon preference index (CPI) was calculated using concentrations of $\mathrm{C}_{24-32} n$-alkanes following Fujii et al. (2015a) and ranged 1.22-1.60, averaging $1.42 \pm 0.10$. Comparable CPI values have been reported previously for laboratory emissions from peat collected in Indonesia (1.5), Germany (1.8) (Iinuma et al., 2007), and North Carolina (1.4-1.5) (George et al., 2016). These CPI values are low in comparison to emissions from foliage, softwood, and hardwood combustion emissions that range 1.66.2 (Hays et al., 2002; Yamamoto et al., 2013). Together, the high $n$-alkane mass fraction and CPI values of $1.4 \pm 0.2$ are characteristic features of Indonesian peat fire emissions.

\subsubsection{Anhydrosugars}

Pyrolysis of cellulose and hemicellulose generates anhydrosugars, of which levoglucosan, mannosan, and galactosan were quantified. Anhydrosugar EF $\left(\mathrm{EF}_{\text {anh }}\right)$ ranged $157-2041 \mathrm{mg} \mathrm{kg}^{-1}$ and averaged $543 \pm 598 \mathrm{mg} \mathrm{kg}^{-1}$. The dominant anhydrosugar was levoglucosan (averaging $46 \pm 40 \mathrm{mg} \mathrm{gOC}^{-1}$ ), followed by mannosan $\left(0.93 \pm 0.76 \mathrm{mg} \mathrm{gOC}^{-1}\right)$ and galactosan $\left(0.14 \pm 1.13 \mathrm{mg} \mathrm{gOC}^{-1}\right)$ (Fig. 5, Table 2). Levoglucosan was the most abundant individual species quantified and contributed $0.3-6.0 \%$ of OC mass (Table S2). A significant correlation was not observed between $\mathrm{EF}_{\mathrm{OC}}$ and $\mathrm{EF}_{\text {levoglucosan }}(p=0.4)$ in contrast to Sullivan et al. (2008), who observed the correlation of these values for biomass 


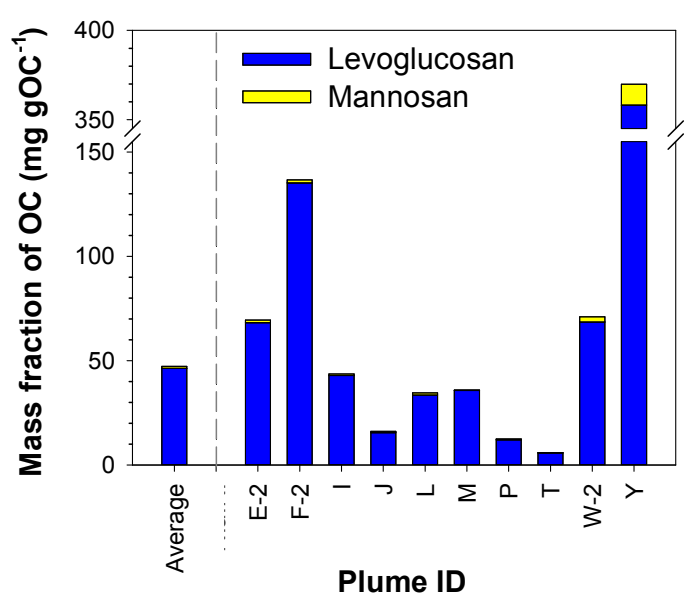

Figure 5. Organic carbon mass fractions of select anhydrosugars for study average and selected individual plumes. Plume $\mathrm{Y}$ was not included in average calculation as discussed in Sect. 2.1. On average, the galactosan mass fraction was $0.14 \mathrm{mg} \mathrm{gOC}^{-1}$ (maximum $=0.77 \mathrm{mg} \mathrm{gOC}^{-1}$ ); due to its low concentrations, it was not included in the plot.

burning emissions from grass, duff, chaparral, softwood, and hardwood fuels $\left(R^{2}=0.68\right)$. The variable cellulose content across peat soils likely contributes to this lack of correlation.

While relative ratios of levoglucosan, mannosan, and galactosan have been used to distinguish between various types of biomass combustion emissions (Engling et al., 2014), peat-burning emissions did not exhibit consistent ratios of these species. The levoglucosan to mannosan ratio ranged widely from 27 to 160 with an average ( \pm standard deviation) of $55 \pm 41$. Meanwhile, Iinuma et al. (2007) reported this ratio to be 11 and Fujii et al. (2015a) reported it to average 15 . Because of the variability across studies and the expected dependence of this ratio on biomass cellulose content and composition (Sullivan et al., 2008), this ratio is insufficient to distinguish peat combustion from other biomass types.

\subsubsection{Lignin decomposition compounds}

$\mathrm{S}, \mathrm{V}, \mathrm{SA}$, and VA derived from lignin pyrolysis were quantified (Fig. 6), with a combined EF ranging $15-154 \mathrm{mg} \mathrm{kg}^{-1}$ and averaging $80 \pm 50 \mathrm{mg} \mathrm{kg}^{-1}$ (Table S2). Correlations among aldehydes ( $\mathrm{V}$ and $\mathrm{S}$ ) were not significant, possibly due to $\mathrm{V}$ partitioning to the gas phase, as indicated by its detection on backup filters, whereas other species (S, VA, and SA) were detected only on front filters indicative of particlephase species. We examined the potential of the VA : SA ratios to be useful in distinguishing this source from other types of biomass burning, since VA:SA depends on the lignin composition of the biomass (Simoneit et al., 1999). A significant moderate correlation was observed between $\mathrm{EF}_{\mathrm{VA}}$ and $\mathrm{EF}_{\mathrm{SA}}\left(R^{2}=0.65 ; p=0.004\right)$. Based on linear regres-

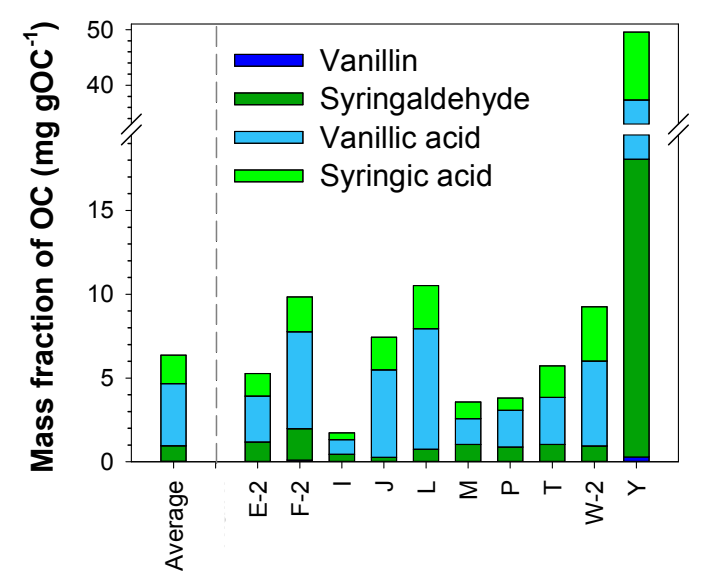

Plume ID

Figure 6. Organic carbon mass fraction of measured lignin decomposition products for study average and selected individual plumes. Plume $\mathrm{Y}$ was not included in average calculation as discussed in Sect. 2.1.

sion analysis, VA : SA was found to be $1.9 \pm 0.2$ for freshly emitted peat smoke in this study (Fig. 7). This value agrees well with observations of VA : SA in $\mathrm{PM}_{2.5}$ in Malaysia affected by Sumatran peat fires, which had a VA : SA ratio of $1.7 \pm 0.4$ (Fujii et al., 2015b) and the ratio of vanillyl phenols to syringyl phenols of 2.0 reported for Kalimantan peat (Orem et al., 1996). Meanwhile, other studies indicate lower VA : SA ratios for near-source emissions of Sumatran peat burning $(1.1 \pm 0.4)$ (Fujii et al., 2015a) and laboratory burning of South Sumatran peat (0.11) (Iinuma et al., 2007). Because other biomasses in South Asia have VA : SA that fall in this range, such as bamboo (1.17) and sugar cane (1.78) ( $\mathrm{Si}$ moneit et al., 1999), this ratio is unlikely to be useful in distinguishing peat burning from other types of biomass burning in the absence of other distinguishing chemical or physical properties. Further, syringyl compounds degrade more quickly in peat compared to vanillyl compounds (Orem et al., 1996) and post-emission SA degrades more quickly than VA by photolysis in the atmosphere, such that VA : SA is likely to increase with smoke transport (Fujii et al., 2015b). Consequently, this ratio has limited utility in source identification and apportionment.

\subsubsection{PAHs, hopanes, and sterols}

PAHs were observed in emissions from Indonesian peat burning and the 18 PAHs that were quantified are listed in Table 2. For the measured species, $\mathrm{EF}_{\mathrm{PAH}}$ ranged 1.7$17 \mathrm{mg} \mathrm{kg}^{-1}$ and were consistent with previously reported

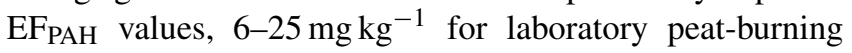
studies (Black et al., 2016; Iinuma et al., 2007). PAH composition was dominated by pyrene, chrysene, methylfluoranthene, fluoranthene, and retene, which accounted for $\sim 56 \%$ 


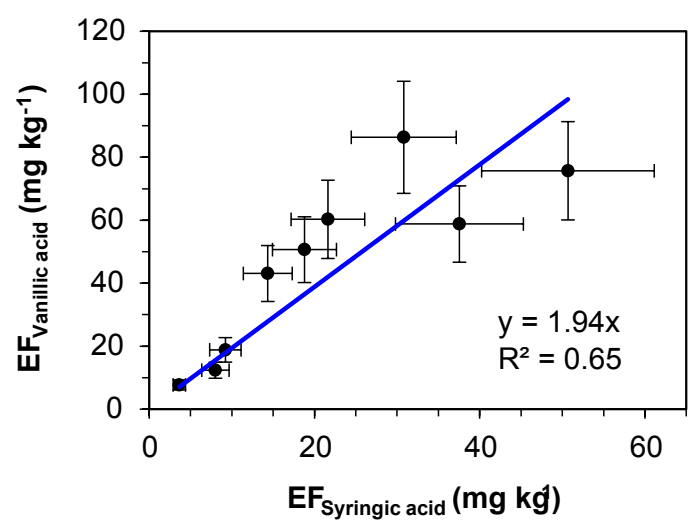

Figure 7. Emission ratios of vanillic acid to syringic acid.

of the measured PAH emissions (Table 2). Several biomass burning studies have reported retene, a biomarker of softwood combustion, as the most abundant PAH in wood smoke (Fine et al., 2002; Hays et al., 2002; Schauer and Cass, 2000), whereas it contributed only $8 \%$ of the measured PAH in this study.

Benz(a)anthracene, benzo(a)pyrene (B[a]P), benzo(b)fluoranthene, benzo(k)fluoranthene, chrysene, and dibenz(a,h)anthracene, which are categorized as probable human carcinogens by the US Environmental Protection Agency (USEPA, 2008), were detected in peat-burning aerosols and together these PAHs accounted for $39 \%$ of total quantified PAH species. The toxic equivalency factor was estimated for quantified PAHs to estimate the overall human health hazard level (Nisbet and LaGoy, 1992). The estimated $\mathrm{B}$ [a]P equivalent toxicity value ranged $0.05-0.39 \mathrm{mg} \mathrm{kg}^{-1}$, averaging $0.13 \pm 0.10 \mathrm{mg} \mathrm{kg}^{-1}$, and was comparable to previously reported toxicity values for peat smoke, such as $0.12-0.16$ by Black et al. (2016). The total PAH concentration in undiluted peat smoke ranged $0.3-18 \mu \mathrm{g} \mathrm{m}^{-3}$ and was similar to PAH concentrations reported for exhaust smoke of a coke oven $\left(25 \mu \mathrm{g} \mathrm{m}^{-3}\right)$, aluminum smelting $\left(15 \mu \mathrm{g} \mathrm{m}^{-3}\right)$, diesel engines $\left(5 \mu \mathrm{g} \mathrm{m}^{-3}\right)$, and gasoline engines $\left(3 \mu \mathrm{g} \mathrm{m}^{-3}\right)$ (Khalili et al., 1995; Armstrong et al., 2004).

To the best of our knowledge, hopanes have not been previously quantified in peat fire emissions. $17 \alpha(\mathrm{H})-22,29,30$ Trisnorhopane, $17 \beta(\mathrm{H})-21 \alpha(\mathrm{H})-30$-norhopane, and $17 \alpha(\mathrm{H})-$ $21 \beta(\mathrm{H})$-hopane were identified using authentic standards and quantified in pure peat smoke for the first time. $\mathrm{EF}_{\text {hopanes }}$ ranged $11-37 \mathrm{mg} \mathrm{kg}^{-1}$, averaging $17 \pm 8 \mathrm{mg} \mathrm{kg}^{-1}$ (Table S2). Terpenoid and hopanoid hydrocarbon compounds that have the hopane skeleton are ubiquitous in peat soils (Ries-Kautt and Albrecht, 1989; Venkatesan et al., 1986; Quirk et al., 1984; López-Días et al., 2010; Del Rio et al., 1992; Dehmer, 1995). Thus, the presence of hopanes in peat smoke is not unexpected. Norhopane had the highest OC mass fraction, followed by trisnorhopane and hopane (Table 2). A fairly consistent ratio of $0.25: 0.60: 0.15$ was observed among trisnorhopane, norhopane, and hopane irrespective of the sam- pling site and burning depth, indicating the formation of hopanes is independent of burning conditions (Fig. S3). The observed hopane ratio is clearly distinct from that of diesel (0.04 : $48: 48)$ (Schauer et al., 1999) and non-catalytic gasoline $(0.10: 0.42: 0.48)$ (Schauer et al., 2002) engine emissions. However, it is comparable to the hopane ratio of lignite $(0.23: 0.66: 0.11)$ and subbituminous $(0.29: 0.49$ : 0.22 ) coal smoke (Oros and Simoneit, 2000). This indicates similarities of terpenoid and hopanoid hydrocarbons in peat soils and coal deposits and these are younger on the geological timescale than crude oil.

Stigmasterol, $\beta$-sitosterol, and campesterol were detected in peat smoke and accounted for $0.14-1.7 \mathrm{mg} \mathrm{gOC}^{-1}$ of OC mass fraction (Table S2). Sterols have been identified in peat soils with a major contribution from $\beta$-sitosterol (Del Rio et al., 1992; López-Días et al., 2010). Similarly, $\beta$-sitosterol is the predominant sterol in PM (Table 2), indicating the emission of peat constituents to the atmosphere as PM during smoldering.

\subsection{Water-soluble inorganic ions}

Water-soluble ions accounted for only $1.1 \%$ of the PM mass and total quantified $\mathrm{EF}_{\text {ions }}$ ranged $45-490 \mathrm{mg} \mathrm{kg}^{-1}$, averaging $201 \pm 144 \mathrm{mg} \mathrm{kg}^{-1}$. Ammonium and chloride were detected in all the samples with average EFs of $92 \pm 61 \mathrm{mg} \mathrm{kg}^{-1}$ and $75 \pm 52 \mathrm{~m} \mathrm{~kg}^{-1}$, respectively. Frequency of detection for sulfate, nitrate, and fluoride was 83,61 , and $56 \%$ and EFs ranged 2-133, 0.2-6.8, and $0.4-45.9 \mathrm{mg} \mathrm{kg}^{-1}$, respectively. PM mass fractions of ammonium vs sulfate $(r=0.95$, $p<0.001)$ and ammonium vs. chloride $(r=0.89, p<0.001)$ were strongly correlated indicating that a major fraction of inorganics in $\mathrm{PM}$ is in the form of $\left(\mathrm{NH}_{4}\right)_{2} \mathrm{SO}_{4}$ and $\mathrm{NH}_{4} \mathrm{Cl}$. The molar concentrations of gaseous $\mathrm{NH}_{3}$ and $\mathrm{NO}+\mathrm{HONO}$ were 33 times and 312 times higher than that of $\mathrm{NH}_{4}^{+}$and $\mathrm{NO}_{3}^{-}$, respectively, consistent with a dominance of gas-phase precursors in fresh peat-burning emissions (Stockwell et al., 2016). The atmospheric oxidation of NO and HONO could increase the concentration of $\mathrm{NO}_{3}^{-}$(Gankanda and Grassian, 2013; Gankanda et al., 2016), while acid-base reactions convert $\mathrm{NH}_{3}$ to $\mathrm{NH}_{4}^{+}$, thus leading to increased concentrations of these secondary inorganic products in aged peat smoke.

Potassium has been used as an indicator of biomass burning, both on its own and in concert with levoglucosan (Simoneit et al., 1999; Sullivan et al., 2008; Chuang et al., 2013; Gao et al., 2003). From peat smoldering fires, extremely low potassium emissions ( $0.03 \%$ of PM mass) were observed, at concentrations too low to be a useful indicator species, as described by Sullivan et al. (2014) and Fujii et al. (2015a).

\subsection{Metals}

Metal species accounted for a maximum of $0.15 \%$ of the PM mass and their EF ranged from below the detection limit to $28 \mathrm{~m} \mathrm{~kg}^{-1}$ in plume $\mathrm{P}$ (which had the highest PM mass 
Table 3. Estimated emissions from Indonesian peat fires during 2015 El Niño, based on a burned area of $8.5 \times 10^{5}$ ha (Whitburn et al., 2016), an average burning depth of $34 \pm 12 \mathrm{~cm}$ (Stockwell et al., 2016), and peat bulk density $0.120 \pm 0.005 \mathrm{~g} \mathrm{~cm}^{-3}$ (Konecny et al., 2016). The uncertainty of the estimated value is propagated using standard deviations of the mean EFs, burn depth, and peat bulk density.

\begin{tabular}{|c|c|c|}
\hline \multirow[t]{2}{*}{ Species } & \multicolumn{2}{|c|}{ Total estimated emission } \\
\hline & $\begin{array}{r}\text { C-mass based } \\
(\mathrm{TgC})\end{array}$ & $\begin{array}{r}\text { Mass based } \\
(\mathrm{Tg})\end{array}$ \\
\hline $\mathrm{PM}_{2.5}$ & - & $6.0 \pm 5.5$ \\
\hline \multicolumn{3}{|l|}{ C-containing compounds } \\
\hline $\mathrm{OC}_{(\mathrm{PM} 2.5)}$ & $4.3 \pm 4.3$ & - \\
\hline $\mathrm{EC}_{(\mathrm{PM} 2.5)}$ & $0.083 \pm 0.081$ & - \\
\hline $\mathrm{CO}_{2(\mathrm{~g})}^{\mathrm{a}}$ & $149 \pm 71$ & $547 \pm 259$ \\
\hline $\mathrm{CO}_{(\mathrm{g})}^{\mathrm{a}}$ & $44 \pm 30$ & $102 \pm 69$ \\
\hline $\mathrm{CH}_{4(\mathrm{~g})}^{\mathrm{a}}$ & $2.5 \pm 2.6$ & $3.3 \pm 3.5$ \\
\hline Other C-containing trace gases ${ }^{\mathrm{a}}$ & $5.5 \pm 1.3$ & $9.3 \pm 2.6$ \\
\hline Total C & $205 \pm 77$ & - \\
\hline \multicolumn{3}{|l|}{ Water-soluble ions in $\mathrm{PM}_{2.5}$} \\
\hline $\mathrm{NH}_{4}^{+}$ & - & $0.032 \pm 0.039$ \\
\hline $\mathrm{Cl}^{-}$ & - & $0.026 \pm 0.032$ \\
\hline $\mathrm{NO}_{3}^{-}$ & - & $0.0010 \pm 0.0013$ \\
\hline $\mathrm{SO}_{4}^{2-}$ & - & $0.0096 \pm 0.0151$ \\
\hline \multicolumn{3}{|l|}{ Other atmospheric gases } \\
\hline $\mathrm{NH}_{3(\mathrm{~g})}^{\mathrm{a}}$ & - & $1.00 \pm 0.91$ \\
\hline $\mathrm{HCl}_{(\mathrm{g})}^{\mathrm{a}}$ & - & $0.012 \pm 0.014$ \\
\hline $\mathrm{NO}_{(\mathrm{g})}^{\mathrm{a}}$ & - & $0.11 \pm 0.17$ \\
\hline $\mathrm{HONO}_{(\mathrm{g})}^{\mathrm{a}}$ & - & $0.073 \pm 0.061$ \\
\hline
\end{tabular}

${ }^{\text {a }}$ EFs are based on Stockwell et al. (2016).

loading on the filter; Table S1). The metal fraction was dominated by $\mathrm{Fe}, \mathrm{Cu}, \mathrm{Zn}$, and $\mathrm{Ba}$, many of which have been previously observed in peat soil (Dizman et al., 2015). The lower $\mathrm{EF}_{\text {metal }}$ values relative to other quantified species (i.e., OC) indicate the minimum influence of re-suspended soil dust to $\mathrm{PM}_{2.5}$. Further, combustion at temperatures lower than $400{ }^{\circ} \mathrm{C}$, indicative of smoldering conditions, precludes metal transfer to the aerosol phase (Raison et al., 1985; Usup et al., 2004).

\subsection{Emission estimates from 2015 Indonesian peat fires}

The emissions from Indonesian peat fires during the $2015 \mathrm{El}$ Niño were estimated using mean EFs calculated in this study for an estimated burned area of $8.5 \times 10^{5}$ ha (Whitburn et al., 2016), an average burning depth of $34 \pm 12 \mathrm{~cm}$ (calculated during this study; Stockwell et al., 2016), and a peat bulk density of $0.120 \pm 0.005 \mathrm{~g} \mathrm{~cm}^{-3}$ (Konecny et al., 2016). The uncertainty of the estimated value is propagated using standard deviation of the mean EFs, burn depth, and peat bulk density. However, the uncertainty of burned area is not defined.
In this way, the total $\mathrm{PM}_{2.5}$ released to the atmosphere from this fire event was estimated to be $3.2-11 \mathrm{Tg}$, averaging $6.0 \pm 5.5 \mathrm{Tg}$ with major contribution from $\mathrm{OC}(4.3 \mathrm{Tg})$ followed by EC $(0.08 \mathrm{Tg})$ and water-soluble ions $(0.07 \mathrm{Tg})$ ( Table 3 ). Combining our OC and EC emission factors with gasphase EFs of $\mathrm{CO}_{2}, \mathrm{CO}, \mathrm{CH}_{4}$, and other carbon-containing gases from Stockwell et al. (2016), we estimate a total carbon emission of $205 \pm 77 \mathrm{TgC}$ to the atmosphere, of which $73 \%$ was as $\mathrm{CO}_{2}(149 \pm 71 \mathrm{TgC}), 21 \%$ as $\mathrm{CO}(44 \pm 30 \mathrm{TgC}), 1.2 \%$ as $\mathrm{CH}_{4}(2.5 \pm 2.6 \mathrm{TgC}), 2.7 \%$ as other carbon-containing gases $(5.5 \pm 1.3 \mathrm{TgC}), 2.1 \%$ as $\mathrm{OC}(4.3 \pm 4.3 \mathrm{TgC})$, and $0.04 \%$ as $\mathrm{EC}(0.083 \pm 0.081 \mathrm{TgC})$. Our carbon emission estimates are in good agreement with Huijnen et al. (2016) who estimated total $\mathrm{C}$ emissions of $227 \pm 67 \mathrm{TgC}$ for this fire event. However, this is $\sim 8$ times lower than the carbon emissions estimated for the 1997-1998 Indonesian peat fires (810-2570 TgC) (Page et al., 2002).

\section{Conclusions}

$\mathrm{PM}_{2.5}$ was collected from authentic in situ peat smoke during the 2015 El Niño peat fire episode in Central Kalimantan, Indonesia, and was chemically characterized for PM mass, EC, OC, water-soluble ions, metals, and organic species. Fuel-based $\mathrm{EF}_{\mathrm{PM}_{2.5}}$ ranged from 6.0 to $29.6 \mathrm{~g} \mathrm{~kg}^{-1}$, averaging $17.3 \pm 6.0 \mathrm{~g} \mathrm{~kg}^{-1}$, and we estimate $3.2-11 \mathrm{Tg}$ of $\mathrm{PM}_{2.5}$ was released to the atmosphere during the 2015 El Niño peat fire episode. OC accounted for the major fraction of PM mass while EC, water-soluble ions, and metal oxides comprised only a minor fraction of PM mass. Combining our $\mathrm{EF}_{\mathrm{OC}}$ and $\mathrm{EF}_{\mathrm{EC}}$ with gas-phase $\mathrm{EFs}$ of $\mathrm{CO}_{2}, \mathrm{CO}, \mathrm{CH}_{4}$, and other carbon-containing gases from Stockwell et al. (2016), we estimate a total carbon emission of $205 \pm 77 \mathrm{TgC}$ to the atmosphere. OC and EC comprised 2.1 and $0.04 \%$ of total carbon emissions, respectively.

Overall, chemical speciation of OC revealed the following characteristics of peat-burning emissions: high OC mass fractions $(72 \%)$, primarily water-insoluble OC $(84 \pm 11 \%$, low EC mass fractions $(1 \%)$, and relatively high $n$-alkane contributions to $\mathrm{OC}(6.2 \% \mathrm{C})$ with odd carbon preference CPI (1.2-1.6). This chemical profile is in good agreement with prior studies of Indonesian peat burning using laboratory measurements (Christian et al., 2003; Iinuma et al., 2007) and ambient aerosol studies in Indonesia (Fujii et al., $2015 \mathrm{a}, \mathrm{b}$ ) as well as laboratory studies of peat emissions from other locations (Black et al., 2016; Geron and Hays, 2013; Chen et al., 2007). The similarities of the peat-burning chemical profiles determined in this in situ emissions characterization and prior and laboratory studies reveal that laboratory studies can accurately capture the fractional composition of PM and OC. However, greater discrepancies arise in the absolute $\mathrm{EF}_{\mathrm{PM}_{2.5}}$ emissions (Table 1) across field and laboratory studies, with the former typically yielding lower $\mathrm{EF}_{\mathrm{PM}_{2.5}}$ values. Differences in EFPM across studies are expected to result 
from several factors, such as fuel composition and moisture content, combustion conditions, and timing and concentration of PM sampling.

Knowledge of chemical characteristics of peat emissions can be used in source identification and apportionment modeling at a receptor site that is impacted by peatland fire emissions. Further, they can allow for assessment of acute and chronic hazards associated with exposures to high concentrations of PM and PAH from peat smoke during the fire season (Armstrong et al., 2004; Kim et al., 2013).

The quantitative emission factors developed in this study for Indonesian peat burning are the most representative of natural peat-burning conditions and may be used to update regional and global emission inventories which are currently based on EFs computed from laboratory studies. The most recent emission inventory compiled by Akagi et al. (2011) does not include an EF value for $\mathrm{PM}_{2.5}$ for peat fire emissions. Further, the $\mathrm{EF}_{\mathrm{OC}}$ reported in Akagi et al. (2011) is $50 \%$ lower than the average $\mathrm{EF}_{\mathrm{OC}}$ observed in this study, which would underestimate the $\mathrm{PM}_{2.5}$ OC emissions observed in the field. Thus, the use of these in situ EFs in updates to emission inventories can provide more accurate emission estimates. Moreover, more studies should be carried out downwind to evaluate the effects of atmospheric dilution and atmospheric photochemical reactions on the chemical composition of peat fire PM.

Data availability. Emissions data for all samples are provided in Table S2.

The Supplement related to this article is available online at https://doi.org/10.5194/acp-18-2585-2018-supplement.

Competing interests. The authors declare that they have no conflict of interest.

Acknowledgements. This research was primarily supported by NASA grant NNX13AP46G to SDSU and UM. The research was also supported by NASA grant NNX14AP45G to UM. We also acknowledge the T. Anne Cleary International Dissertation Research Fellowship awarded by the Graduate College, University of Iowa, and Center for Global and Reginal Environmental Research (CGRER) graduate student travel award for field research. We also thank David Peate, Iowa Trace Element Analysis Laboratory, for the assistance given during metal analysis. We are also grateful to Laura Graham, Grahame Applegate, and the BOS field team for their excellent support during the sample collection.

Edited by: Vassiliki Kotroni

Reviewed by: Earle Williams and one anonymous referee

\section{References}

Akagi, S. K., Yokelson, R. J., Wiedinmyer, C., Alvarado, M. J., Reid, J. S., Karl, T., Crounse, J. D., and Wennberg, P. O.: Emission factors for open and domestic biomass burning for use in atmospheric models, Atmos. Chem. Phys., 11, 4039-4072, https://doi.org/10.5194/acp-11-4039-2011, 2011.

Al-Naiema, I., Estillore, A. D., Mudunkotuwa, I. A., Grassian, V. H., and Stone, E. A.: Impacts of Co-firing Biomass on Emissions of Particulate Matter to the Atmosphere, Fuel, 162, 111120, 2015.

Andreae, M. O. and Merlet, P.: Emission of Trace Gases and Aerosols from Biomass Burning, Global Biogeochem. Cy., 15, 955-966, 2001.

Armstrong, B., Hutchinson, E., Unwin, J., and Fletcher, T.: Lung Cancer Risk after Exposure to Polycyclic Aromatic Hydrocarbons: A Review and Meta-analysis, Environ. Health Perspect., 112, 970-978, 2004.

Baker, E.: Chemistry and Morphology of Plant Epicuticular Waxes, in: The Plant Cuticle, edited by: Cutler, D. F., Alvin, K. L., Price, C. E., London: Academic Press, 139-166, 1982,

Benner, W. H.: Photochemical Reactions of Forest Fire Combustion Products, Ph.D. Thesis, Univ. Florida, Gainesville, FL, 1977.

bin Abas, M. R., Oros, D. R., and Simoneit, B. R.: Biomass Burning as the Main Source of Organic Aerosol Particulate Matter in Malaysia During Haze Episodes, Chemosphere, 55, 1089-1095, 2004.

Black, R. R., Aurell, J., Holder, A., George, I. J., Gullett, B. K., Hays, M. D., Geron, C. D., and Tabor, D.: Characterization of Gas and Particle Emissions from Laboratory Burns of Peat, Atmos. Environ., 132, 49-57, 2016.

Bond, T. C. and Bergstrom, R. W.: Light Absorption by Carbonaceous Particles: An Investigative Review, Aerosol Sci. Technol., 40, 27-67, 2006.

Chen, L.-W. A., Moosmüller, H., Arnott, W. P., Chow, J. C., Watson, J. G., Susott, R. A., Babbitt, R. E., Wold, C. E., Lincoln, E. N., and Hao, W. M.: Emissions from Laboratory Combustion of Wildland Fuels: Emission Factors and Source Profiles, Environ. Sci. Technol., 41, 4317-4325, 2007.

Chisholm, R. A., Wijedasa, L. S., and Swinfield, T.: The Need for Long-term Remedies for Indonesia's Forest Fires, Conserv. Biol., 30, 5-6, 2016.

Christian, T. J., Kleiss, B., Yokelson, R. J., Holzinger, R., Crutzen, P., Hao, W. M., Saharjo, B., and Ward, D. E.: Comprehensive Laboratory Measurements of Biomassburning Emissions: 1. Emissions from Indonesian, African, and Other Fuels, J. Geophys. Res.-Atmos., 108, 4719, https://doi.org/10.1029/2003JD003704, 2003.

Chuang, M.-T., Chou, C. C.-K., Sopajaree, K., Lin, N.-H., Wang, J.L., Sheu, G.-R., Chang, Y.-J., and Lee, C.-T.: Characterization of Aerosol Chemical Properties from Near-source Biomass Burning in the Northern Indochina During 7-SEAS/Dongsha Experiment, Atmos. Environ., 78, 72-81, 2013.

Dehmer, J.: Petrological and Organic Geochemical Investigation of Recent Peats with Known Environments of Deposition, Int. J. Coal Geol., 28, 111-138, 1995.

Del Rio, J., Gonzalez-Vila, F., and Martin, F.: Variation in the Content and Distribution of Biomarkers in Two Closely Situated Peat and Lignite Deposits, Org. Geochem., 18, 67-78, 1992. 
Dizman, M., Tutar, A., and Horuz, A.: The Characterization of the Arifiye Peat, J. Chem. Soc. Pak., 37, 131-138, 2015.

Dusek, U., Frank, G., Helas, G., Iinuma, Y., Zeromskiene, K., Gwaze, P., Hennig, T., Massling, A., Schmid, O., and Herrmann, H.: "Missing" Cloud Condensation Nuclei in Peat Smoke, Geophys. Res. Lett., 32, L11802, https://doi.org/10.1029/2005GL022473, 2005.

Engling, G., He, J., Betha, R., and Balasubramanian, R.: Assessing the regional impact of indonesian biomass burning emissions based on organic molecular tracers and chemical mass balance modeling, Atmos. Chem. Phys., 14, 8043-8054, https://doi.org/10.5194/acp-14-8043-2014, 2014.

Ficken, K., Barber, K., and Eglinton, G.: Lipid Biomarker, $\delta$ 13C and Plant Macrofossil Stratigraphy of a Scottish Montane Peat Bog Over the Last Two Millennia, Org. Geochem., 28, 217-237, 1998.

Fine, P. M., Cass, G. R., and Simoneit, B. R.: Chemical Characterization of Fine Particle Emissions from the Fireplace Combustion of Woods Grown in the Southern United States, Environ. Sci. Technol., 36, 1442-1451, 2002.

Fujii, Y., Iriana, W., Oda, M., Puriwigati, A., Tohno, S., Lestari, P., Mizohata, A., and Huboyo, H. S.: Characteristics of Carbonaceous Aerosols Emitted from Peatland Fire in Riau, Sumatra, Indonesia, Atmos. Environ., 87, 164-169, 2014.

Fujii, Y., Kawamoto, H., Tohno, S., Oda, M., Iriana, W., and Lestari, P.: Characteristics of Carbonaceous Aerosols Emitted from Peatland Fire in Riau, Sumatra, Indonesia (2): Identification of Organic Compounds, Atmos. Environ., 110, 1-7, 2015a.

Fujii, Y., Tohno, S., Amil, N., Latif, M. T., Oda, M., Matsumoto, J., and Mizohata, A.: Annual variations of carbonaceous $\mathrm{PM}_{2.5}$ in Malaysia: influence by Indonesian peatland fires, Atmos. Chem. Phys., 15, 13319-13329, https://doi.org/10.5194/acp-15-133192015, 2015b.

Gankanda, A. and Grassian, V. H.: Nitrate Photochemistry in NaY Zeolite: Product Formation and Product Stability under Different Environmental Conditions, J. Phys. Chem. A, 117, 2205-2212, 2013

Gankanda, A., Coddens, E. M., Zhang, Y., Cwiertny, D. M., and Grassian, V. H.: Sulfate Formation Catalyzed by Coal Fly Ash, Mineral Dust and Iron (iii) Oxide: Variable Influence of Temperature and Light, Environmental Science: Processes \& Impacts, 2016.

Gao, S., Hegg, D. A., Hobbs, P. V., Kirchstetter, T. W., Magi, B. I., and Sadilek, M.: Water-soluble Organic Components in Aerosols Associated with Savanna Fires in Southern Africa: Identification, Evolution, and Distribution, J. Geophys. Res.-Atmos., 108, 8491, https://doi.org/10.1029/2002JD002324, 2003.

Ge, C., Wang, J., and Reid, J. S.: Mesoscale modeling of smoke transport over the Southeast Asian Maritime Continent: coupling of smoke direct radiative effect below and above the low-level clouds, Atmos. Chem. Phys., 14, 159-174, https://doi.org/10.5194/acp-14-159-2014, 2014.

George, I. J., Black, R. R., Geron, C. D., Aurell, J., Hays, M. D., Preston, W. T., and Gullett, B. K.: Volatile and Semivolatile Organic Compounds in Laboratory Peat Fire Emissions, Atmos. Environ., 132, 163-170, 2016.

Geron, C. and Hays, M.: Air Emissions from Organic Soil Burning on the Coastal Plain of North Carolina, Atmos. Environ., 64, 192-199, 2013.
Glover, D. and Jessup, T.: Indonesia's Fires and Haze: The Cost of Catastrophe, IDRC, 2006.

Hatch, L. E., Luo, W., Pankow, J. F., Yokelson, R. J., Stockwell, C. E., and Barsanti, K. C.: Identification and quantification of gaseous organic compounds emitted from biomass burning using two-dimensional gas chromatography-time-offlight mass spectrometry, Atmos. Chem. Phys., 15, 1865-1899, https://doi.org/10.5194/acp-15-1865-2015, 2015.

Hays, M. D., Geron, C. D., Linna, K. J., Smith, N. D., and Schauer, J. J.: Speciation of Gas-phase and Fine Particle Emissions from Burning of Foliar Fuels, Environ. Sci. Technol., 36, 2281-2295, 2002.

Huat, B. B., Kazemian, S., Prasad, A., and Barghchi, M.: State of an Art Review of Peat: General Perspective, Int. J. Phys. Sci., 6, 1988-1996, 2011.

Huijnen, V., Wooster, M., Kaiser, J., Gaveau, D., Flemming, J., Parrington, M., Inness, A., Murdiyarso, D., Main, B., and van Weele, M.: Fire Carbon Emissions Over Maritime Southeast Asia in 2015 Largest Since 1997, Scientific reports, 6, 26886, 2016.

Iinuma, Y., Brüggemann, E., Gnauk, T., Müller, K., Andreae, M., Helas, G., Parmar, R., and Herrmann, H.: Source Characterization of Biomass Burning Particles: The Combustion of Selected European Conifers, African Hardwood, Savanna Grass, and German and Indonesian Peat, J. Geophys. Res.-Atmos., 112, D08209, https://doi.org/10.1029/2006jd007120, 2007.

Jayarathne, T., Stockwell, C. E., Yokelson, R. J., Nakao, S., and Stone, E. A.: Emissions of Fine Particle Fluoride from Biomass Burning, Environ. Sci. Technol., 48, 12636-12644, 2014.

Khalili, N. R., Scheff, P. A., and Holsen, T. M.: PAH Source Fingerprints for Coke Ovens, Diesel and, Gasoline Engines, Highway Tunnels, and Wood Combustion Emissions, Atmos. Environ., 29, 533-542, 1995.

Kim, K.-H., Jahan, S. A., Kabir, E., and Brown, R. J.: A Review of Airborne Polycyclic Aromatic Hydrocarbons (PAHs) and their Human Health Effects, Environ. Int., 60, 71-80, 2013.

Konecny, K., Ballhorn, U., Navratil, P., Jubanski, J., Page, S. E., Tansey, K., Hooijer, A., Vernimmen, R., and Siegert, F.: Variable Carbon Losses from Recurrent Fires in Drained Tropical Peatlands, Global Change Biol., 22, 1469-1480, 2016.

Koplitz, S. N., Mickley, L. J., Marlier, M. E., Buonocore, J. J., Kim, P. S., Liu, T., Sulprizio, M. P., DeFries, R. S., Jacob, D. J., and Schwartz, J.: Public Health Impacts of the Severe Haze in Equatorial Asia in September-October 2015: Demonstration of a New Framework for Informing Fire Management Strategies to Reduce Downwind Smoke Exposure, Environ. Res. Lett., 11, 094023, https://doi.org/10.1088/1748-9326/11/9/094023, 2016.

Langner, A. and Siegert, F.: Spatiotemporal Fire Occurrence in Borneo over a Period of 10 Years, Global Change Biol., 15, 48-62, 2009.

López-Días, V., Borrego, Á., Blanco, C., Arboleya, M., López-Sáez, J. A., and López-Merino, L.: Biomarkers in a Peat Deposit in Northern Spain (Huelga de Bayas, Asturias) as Proxy for Climate Variation, J. Chromatogr. A, 1217, 3538-3546, 2010.

Maltby, E. and Immirzi, P.: Carbon Dynamics in Peatlands and Other Wetland Soils Regional and Global Perspectives, Chemosphere, 27, 999-1023, 1993.

May, A., McMeeking, G., Lee, T., Taylor, J., Craven, J., Burling, I., Sullivan, A., Akagi, S., Collett, J., and Flynn, M.: Aerosol Emissions from Prescribed Fires in the United 
States: A Synthesis of Laboratory and Aircraft Measurements, J. Geophys. Res.-Atmos., 119, 11826-11849, https://doi.org/10.1002/2014JD021848, 2014.

McMahon, C. K., Wade, D. D., and Tsoukalas, S. N.: Combustion Characteristics and Emissions from Burning Organic Soils, 73rd Annual Meeting of the Air Pollution Control Association, Montreal, Quebec, 22-27 June, 2-16, , 1980.

McMeeking, G. R., Kreidenweis, S. M., Baker, S., Carrico, C. M., Chow, J. C., Collett, J. L., Hao, W. M., Holden, A. S., Kirchstetter, T. W., and Malm, W. C.: Emissions of Trace Gases and Aerosols During the Open Combustion of Biomass in the Laboratory, J. Geophys. Res.-Atmos., 114, D19210, https://doi.org/10.1029/2009JD011836, 2009.

NIOSH: Diesel Particulate Matter (as Elemental Carbon), Method 5040. NIOSH Manual of Analytical Methods, 2003.

Nisbet, I. C. and LaGoy, P. K.: Toxic Equivalency Factors (TEFs) for Polycyclic Aromatic Hydrocarbons (PAHs), Regul. Toxicol. Pharm., 16, 290-300, 1992.

Orem, W. H., Neuzil, S. G., Lerch, H. E., and Cecil, C. B.: Experimental early-stage coalification of a peat sample and a peatified wood sample from Indonesia, Org. Geochem., 24, 111-125, https://doi.org/10.1016/0146-6380(96)00012-5, 1996.

Oros, D. and Simoneit, B.: Identification and Emission Rates of Molecular Tracers in Coal Smoke Particulate Matter, Fuel, 79, 515-536, 2000.

Oros, D. R. and Simoneit, B. R.: Identification and Emission Factors of Molecular Tracers in Organic Aerosols from Biomass Burning Part 1. Temperate Climate Conifers, Appl. Geochem., 16, 15131544, 2001a.

Oros, D. R. and Simoneit, B. R.: Identification and Emission Factors of Molecular Tracers in Organic Aerosols from Biomass Burning Part 2. Deciduous Trees, Appl. Geochem., 16, 1545-1565, 2001b.

Page, S. E., Hoscilo, A., Langner, A., Tansey, K., Siegert, F., Limin, S., and Rieley, J.: Tropical Peatland Fires in Southeast Asia, in: Tropical Fire Ecology, Springer, 263-287, 2009.

Page, S. E., Siegert, F., Rieley, J. O., Boehm, H.-D. V., Jaya, A., and Limin, S.: The Amount of Carbon Released from Peat and Forest Fires in Indonesia During 1997, Nature, 420, 61-65, 2002.

Parker, R. J., Boesch, H., Wooster, M. J., Moore, D. P., Webb, A. J., Gaveau, D., and Murdiyarso, D.: Atmospheric $\mathrm{CH}_{4}$ and $\mathrm{CO}_{2}$ enhancements and biomass burning emission ratios derived from satellite observations of the 2015 Indonesian fire plumes, Atmos. Chem. Phys., 16, 10111-10131, https://doi.org/10.5194/acp-1610111-2016, 2016.

Peate, D. W., Breddam, K., Baker, J. A., Kurz, M. D., Barker, A. K., Prestvik, T., Grassineau, N., and Skovgaard, A. C.: Compositional characteristics and spatial distribution of enriched Icelandic mantle components, J. Petrol., 51, 1447-1475, https://doi.org/10.1093/petrology/egq025, 2010.

Quirk, M., Wardroper, A., Wheatley, R., and Maxwell, J.: Extended Hopanoids in Peat Environments, Chem. Geol., 42, 25-43, 1984.

Raison, R., Khanna, P., and Woods, P.: Mechanisms of Element Transfer to the Atmosphere During Vegetation Fires, Can. J. Forest Res., 15, 132-140, 1985.

Reid, J. S., Koppmann, R., Eck, T. F., and Eleuterio, D. P.: A review of biomass burning emissions part II: intensive physical properties of biomass burning particles, Atmos. Chem. Phys., 5, 799825, https://doi.org/10.5194/acp-5-799-2005, 2005.
Reid, J. S., Hyer, E. J., Johnson, R. S., Holben, B. N., Yokelson, R. J., Zhang, J. L., Campbell, J. R., Christopher, S. A., Di Girolamo, L., Giglio, L., Holz, R. E., Kearney, C., Miettinen, J., Reid, E. A., Turk, F. J., Wang, J., Xian, P., Zhao, G. Y., Balasubramanian, R., Chew, B. N., Janjai, S., Lagrosas, N., Lestari, P., Lin, N. H., Mahmud, M., Nguyen, A. X., Norris, B., Oanh, N. T. K., Oo, M., Salinas, S. V., Welton, E. J., and Liew, S. C.: Observing and understanding the Southeast Asian aerosol system by remote sensing: An initial review and analysis for the Seven Southeast Asian Studies (7SEAS) program, Atmos. Res., 122, 403-468, https://doi.org/10.1016/j.atmosres.2012.06.005, 2013.

Ries-Kautt, M. and Albrecht, P.: Hopane-derived Triterpenoids in Soils, Chem. Geol., 76, 143-151, 1989.

Rosman, K. and Taylor, P.: Report of the IUPAC Subcommittee for Isotopic Abundance Measurements, Pure Appl. Chem, 71, 15931607, 1999.

Schauer, J. J. and Cass, G. R.: Source Apportionment of Wintertime Gas-phase and Particle-phase Air Pollutants using Organic Compounds as Tracers, Environ. Sci. Technol., 34, 1821-1832, 2000.

Schauer, J. J., Kleeman, M. J., Cass, G. R., and Simoneit, B. R.: Measurement of Emissions from Air Pollution Sources. 2. $\mathrm{C}_{1}$ through $\mathrm{C}_{30}$ Organic Compounds from Medium Duty Diesel Trucks, Environ. Sci. Technol., 33, 1578-1587, 1999.

Schauer, J. J., Kleeman, M. J., Cass, G. R., and Simoneit, B. R.: Measurement of Emissions from Air Pollution Sources. 5. $\mathrm{C}_{1}$ $\mathrm{C}_{32}$ Organic Compounds from Gasoline-powered Motor Vehicles, Environ. Sci. Technol., 36, 1169-1180, 2002.

Simoneit, B. R., Schauer, J. J., Nolte, C., Oros, D. R., Elias, V. O., Fraser, M., Rogge, W., and Cass, G. R.: Levoglucosan, a tracer for cellulose in biomass burning and atmospheric particles, Atmos. Environ., 33, 173-182, https://doi.org/10.1016/S13522310(98)00145-9, 1999.

Stockwell, C. E., Yokelson, R. J., Kreidenweis, S. M., Robinson, A. L., DeMott, P. J., Sullivan, R. C., Reardon, J., Ryan, K. C., Griffith, D. W. T., and Stevens, L.: Trace gas emissions from combustion of peat, crop residue, domestic biofuels, grasses, and other fuels: configuration and Fourier transform infrared (FTIR) component of the fourth Fire Lab at Missoula Experiment (FLAME-4), Atmos. Chem. Phys., 14, 9727-9754, https://doi.org/10.5194/acp-14-9727-2014, 2014.

Stockwell, C. E., Veres, P. R., Williams, J., and Yokelson, R. J.: Characterization of biomass burning emissions from cooking fires, peat, crop residue, and other fuels with high-resolution proton-transfer-reaction time-of-flight mass spectrometry, Atmos. Chem. Phys., 15, 845-865, https://doi.org/10.5194/acp-15845-2015, 2015.

Stockwell, C. E., Jayarathne, T., Cochrane, M. A., Ryan, K. C., Putra, E. I., Saharjo, B. H., Nurhayati, A. D., Albar, I., Blake, D. R., Simpson, I. J., Stone, E. A., and Yokelson, R. J.: Field measurements of trace gases and aerosols emitted by peat fires in Central Kalimantan, Indonesia, during the 2015 El Ninõ, Atmos. Chem. Phys., 16, 11711-11732, https://doi.org/10.5194/acp-16-117112016, 2016.

Stone, E. A., Nguyen, T. T., Pradhan, B. B., and Dangol, P. M.: Assessment of Biogenic Secondary Organic Aerosol in the Himalayas, Environ. Chem., 9, 263-272, 2012.

Sullivan, A., Holden, A., Patterson, L., McMeeking, G., Kreidenweis, S., Malm, W., Hao, W., Wold, C., and Collett, J.: 
A method for Smoke Marker Measurements and its Potential Application for Determining the Contribution of Biomass Burning from Wildfires and Prescribed Fires to Ambient $\mathrm{PM}_{2.5}$ Organic Carbon, J. Geophys. Res.-Atmos., 113, D22302, https://doi.org/10.1029/2008JD010216, 2008.

Sullivan, A. P., May, A. A., Lee, T., McMeeking, G. R., Kreidenweis, S. M., Akagi, S. K., Yokelson, R. J., Urbanski, S. P., and Collett Jr., J. L.: Airborne characterization of smoke marker ratios from prescribed burning, Atmos. Chem. Phys., 14, 1053510545, https://doi.org/10.5194/acp-14-10535-2014, 2014.

Tacconi, L.: Fires in Indonesia: Causes, Costs and Policy Implications, CIFOR, Bogor, Indonesia, 2003.

USEPA: Method 3052: Microwave Assisted Acid Digestion of Siliceous and Organically Based Matrices, Test Methods for Evaluating Solid Waste, 1995.

USEPA: Polycyclic Aromatic Hydrocarbons (PAHs)-EPA Fact Sheet. Washington, DC: National Center for Environmental Assessment, Officeof Research and Development, Environmental Protection Agency, 2008.

Usup, A., Hashimoto, Y., Takahashi, H., and HAYASAKA, H.: Combustion and Thermal Characteristics of Peat Fire in Tropical Peatland in Central Kalimantan, Indonesia, Tropics, 14, 1-19, 2004.

van der Werf, G. R., Randerson, J. T., Giglio, L., Collatz, G. J., Mu, M., Kasibhatla, P. S., Morton, D. C., DeFries, R. S., Jin, Y., and van Leeuwen, T. T.: Global fire emissions and the contribution of deforestation, savanna, forest, agricultural, and peat fires (1997-2009), Atmos. Chem. Phys., 10, 11707-11735, https://doi.org/10.5194/acp-10-11707-2010, 2010.

Venkatesan, M., Ruth, E., and Kaplan, I.: Terpenoid Hydrocarbons in Hula Peat: Structure and Origins, Geochim. Cosmochim. Acta, 50, 1133-1139, 1986.

Wang, J., Ge, C., Yang, Z. F., Hyer, E. J., Reid, J. S., Chew, B. N., Mahmud, M., Zhang, Y. X., and Zhang, M. G.: Mesoscale modeling of smoke transport over the Southeast Asian Maritime Continent: Interplay of sea breeze, trade wind, typhoon, and topography, Atmos. Res., 122, 486-503, https://doi.org/10.1016/j.atmosres.2012.05.009, 2013.

Ward, D.: Factors Influencing the Emissions of Gases and Particulate Matter from Biomass Burning, in: Fire in the Tropical Biota, Springer, 418-436, 1990.
Whitburn, S., Van Damme, M., Clarisse, L., Turquety, S., Clerbaux, C., and Coheur, P. F.: Doubling of Annual Ammonia Emissions from the Peat Fires in Indonesia During the 2015 El Niño, Geophys. Res. Lett., 43, 11007-11014, https://doi.org/10.1002/2016GL070620, 2016.

WHO: Air Quality Guidelines for Particulate Matter, Ozone, Nitrogen Dioxide and Sulfur Dioxide, World Health Organization, Global Update 2005, Summary of Risk Assessment, 2005.

World Bank: The cost of fire: an economic analysis of Indonesia's 2015 fire crisis. Indonesia sustainable landscapes knowledge; note no. 1, Washington, D.C.: World Bank Group, available at: http://documents.worldbank.org/curated/en/776101467990969768/Thecost-of-fire-an-economic-analysis-of-Indonesia-s- 2015-firecrisis (last access: 16 February 2018), 2016.

Yamamoto, S., Kawamura, K., Seki, O., Kariya, T., and Lee, M.: Influence of Aerosol Source Regions and Transport Pathway on $\delta \mathrm{D}$ of Terrestrial Biomarkers in Atmospheric Aerosols from the East China Sea, Geochim. Cosmochim. Acta, 106, 164-176, 2013.

Yokelson, R. J., Griffith, D. W. T., and Ward, D. E.: Openpath Fourier transform infrared studies of large-scale laboratory biomass fires, J. Geophys. Res.-Atmos. (1984-2012), 101, 21067-21080, https://doi.org/10.1029/96JD01800, 1996.

Yokelson, R. J., Susott, R., Ward, D. E., Reardon, J., and Griffith, D. W.: Emissions from Smoldering Combustion of Biomass Measured by Open-path Fourier Transform Infrared Spectroscopy, J. Geophys. Res.-Atmos., 102, 18865-18877, 1997.

Yu, Z., Loisel, J., Brosseau, D. P., Beilman, D. W., and Hunt, S. J.: Global Peatland Dynamics Since the Last Glacial Maximum, Geophys. Res. Lett., 37, L13402, https://doi.org/10.1029/2010GL043584, 2010.

Zulkifley, M. T. M., Ng, T. F., Abdullah, W. H., Raj, J. K., Shuib, M. K., Ghani, A. A., and Ashraf, M. A.: Geochemical Characteristics of a Tropical Lowland Peat Dome in the Kota SamarahanAsajaya Area, West Sarawak, Malaysia, Environ. Earth Sci., 73 1443-1458, 2015. 